\title{
The emergence of biosphere entrepreneurship: are social and business entrepreneurship obsolete?
}

\author{
Howard H. Frederick \\ Tecnológico de Monterrey, \\ Puebla, Mexico \\ and \\ Plymouth State University, \\ 17 High Street, MSC 27, Plymouth, \\ New Hampshire, 03264, USA \\ Email: hhfrederick@plymouth.edu
}

\begin{abstract}
This article combines entrepreneurship, economics and sustainability to build a new theory of biosphere entrepreneurship. Going beyond business and social entrepreneurship, which add value to economic and social spheres, respectively, biosphere entrepreneurship adds value to the biosphere. The purpose of this article is to define biosphere entrepreneurship, and to devise and extend mental models (frameworks) relating entrepreneurship and climate change in order to facilitate theory building. Using images and visual depictions, the article elaborates a series of illustrative candidate frameworks that suggest a theoretical model of biosphere entrepreneurship. The article aims to show how the Earth, humanity, and the economy are connected through negative and positive entrepreneurship. It extends extant frameworks from the fields of financial and capital, entrepreneurial allocation, risk and survival, value and disvalue creation, growth and de-growth, socio-cultural frameworks, and entrepreneurial opportunity in order to substantiate the existence of entrepreneurial activity that adds value to Earth. The article concludes with implications for entrepreneurship education. What should educators be doing to help our young entrepreneurs come to grips with existential and catastrophic risks to the planet? (Includes 11 colour figures)
\end{abstract}

Keywords: value creation; opportunity recognition; entrepreneurship; development; biosphere; social entrepreneurship; business entrepreneurship; climate change; sustainable development; economic growth; small business.

Reference to this paper should be made as follows: Frederick, H.H. (2018) 'The emergence of biosphere entrepreneurship: are social and business entrepreneurship obsolete?', Int. J. Entrepreneurship and Small Business, Vol. 34, No. 3, pp.381-419.

Biographical notes: Howard H. Frederick holds a PhD from the American U and resides at the Plymouth State University in the Lakes Region of New Hampshire, USA where he specialises in entrepreneurship education. He also holds appointments at Tecnológico de Monterrey in Mexico and Anaheim University. He is winner of the Australian Award for Excellence in Educational Publishing.

This paper is a revised and expanded version of a paper entitled 'Understanding bioentrepreneurship: a framework approach' presented at United States Association for Small Business and Entrepreneurship (USASBE), USA, 19-22 January 2017. 


\section{Ontology and entrepreneurship}

Ontological analysis builds frameworks or theoretical constructs to describe phenomena that can be said to exist (Hofwebwer, 2004). We use the concept of 'entrepreneurship ontology' in the tradition of Kuratko et al. (2015), Schindehutte et al. (2000) and Morris et al. (2001b), who, within our field, have led in the use of framework analysis. A framework is an abstract construct (often an image or visual depiction) that researchers contrive to identify, compare, and contrast theoretical constructs. The goal of this approach is to convert abstraction into order, prioritise variables, and identify relationships about phenomena about which experts and observers increasingly are reaching consensus. Using frameworks, researchers develop theories that explain and predict phenomena. As any single framework may cover only particular aspects of a phenomenon, the grander goal is to generate a 'meta-framework of frameworks' to create mental models through which partial observations are juxtaposed to be helpful in theory-building [Warriner, (1984), pp.3-34].

The purpose of this article is to identify frameworks that may have explanatory or predictive power, or simplicity, or may integrate well into or elegantly extend existing frameworks. In the present endeavour, we seek candidate frameworks combining the domains of entrepreneurship, economics, and sustainability to develop a theory of biosphere entrepreneurship.

\section{What is biosphere entrepreneurship?}

Considerable research has shown that entrepreneurs play an important role in the transformation towards a more socially and environmentally sustainable world (e.g., Azmat, 2013; Kirkwood and Walton, 2014; Majid and Yaqun, 2016; Markman et al., 2016; Schaper, 2010; Thurman, 2016; Walton and Kirkwood, 2013). Yet there are multitudes of examples where entrepreneurs have done the opposite and have plundered Earth's resources with impunity, and have thus contributed to existential risks to the planet [Frederick et al., (2016), pp.3-4, 48, 64, 74-75, 129-130, 139-141; Penn, 2003]. Some types of entrepreneurial activity may be inconsistent with the need to conserve the planet and prevent environmental damage. As Shepherd et al. (2013, p.1251) argue, "some...entrepreneurs decide to act in ways that result in harm to the natural environment...perceive[ing] opportunities that harm the environment as highly attractive."

Economic activity has affected the natural environment over the millennia (Crate and Nuttall, 2016). On balance, entrepreneurs have undervalued biodiversity, ecosystems, and the means of survival that nature provides, including resources such as energy, water, free space, and materials. They have often not valued nature as a living ecosystem and have devalued it as a source of natural capital. Rather than adding value to the Earth, entrepreneurs have sometimes aimed only to reduce the quantity of waste that is returned to the planet. In the end, government has had to implement complex regulations, incentives and tools to penalise entrepreneurs or to encourage them not only to reduce waste but also to mitigate the effects of their negative activity. 
The research literature on sustainability and the economy has grown over the years. Malthus (1878), Carson et al. (1962), Boulding (1996), Ehrlich (1968), and Meadows (1972) presaged the development of the modern works. Many authors (Burns and Witoszek, 2012; MacNeill, 2013) consider the modern sustainability literature to have begun with the publication of Our Common Future, known as the Brundtland Commission Report (1987). Brundtland examined the relationship of the economy with natural systems and environmental health. It outlined how the world's population was already living well beyond the planet's means to replenish natural resources, absorb pollution, and regulate important climatic conditions. Brundtland gave us the most widely used definition of sustainability as "[meeting] the needs of the present without compromising the ability of future generations to meet their own needs." It argued that the economy was having a negative impact but that it was still not too late to improve the natural environment while at the same time achieving economic growth [Brundtland, (1987), pp.3-27]. Two decades later the Stern (2007) report on The Economics of Climate Change maintained that climate change was the greatest market failure ever seen. The second Stern report and (Stern and Calderon, 2014) provided a positive spin: there was no need to choose between fighting climate change and growing the world's economy. One could do both at the same time. IPCC's Rajendra Pachauri concurred, "Entrepreneurs who respond to the challenge will reap commercial success - while businesses which fail to do so face oblivion" (Wright, 2009).

Some authors (i.a. Lowitt, 2014; Dean and McMullen, 2007; Nagler, 2012; Patchell and Hayter, 2013; Grisham, 2009; Rodgers, 2010) have suggested that existential risks such as climate change provide opportunities for entrepreneurs. Elkington and Burke's (1989) Green Capitalists argued that environmentalism is in the entrepreneur's best long-term interests. Bennett's (1991) Ecopreneuring focused on opportunities for innovative entrepreneurs to create growth-oriented eco-businesses. Berle (1991), Blue (1991) and Anderson and Leal (1997) used terms like enviro-capitalists, environmental and green entrepreneurs. Porritt's (2007) Capitalism as if the World Matters argued that the only way to save the world from environmental catastrophe was to embrace a new type of capitalism.

Throughout history, we see three types of entrepreneurs: Entrepreneur mercatorius seeks to add value to the private purse through commercial exchange. Entrepreneur socialis adds value to the community and society. Entrepreneur biosphaeris adds value to the biosphere and ecosystem services. Let us argue that the term biosphere entrepreneurship describes entrepreneurial activity that generates value for the biosphere and ecosystem services. The sparse literature [Bergstrand et al., 2011; Björk, 2011; Björk and Olsson, 2013; Fry, 2013; Swedish Ministry of Environment (2014), pp.75, 102; George and Reed, 2015; Hofstra, 2015; Orihuela, 2017; Frederick, 2017] summarises the main characteristics of biosphere entrepreneurs (see Table 1). These characteristics are elucidated in the article using ontological frameworks culminating in a tentative theory of biosphere entrepreneurship. 
Table 1 Characteristics of biosphere entrepreneurs

Biosphere entrepreneurs

- Add value to the biosphere rather than irreplaceably extracting resources from it

- Improve human well-being while safeguarding natural ecosystems

- Utilise ecosystem services and return them to nature with neutral or net-positive end effects

- Up-cycle products and waste, producing a product of higher value than the original

- Balance the relationship between humans and nature

- Promote resilience (ability of the planet to recover)

- Solve problems related to the biosphere and to sustainability dimensions (ecological, social and economic)

- Are capable of learning to work with natural uncertainty

- Use nature's patterns to identify opportunities

- Put profits into generation/regeneration of ecosystem services

\section{Research questions}

In proposing a third kind of entrepreneurship beyond business and social entrepreneurship, the research questions are necessarily exploratory. Is there something there? Can we sort observations into categories? Can we extend existing frameworks to cover this new category? Can we envision a 'framework of frameworks' that ties together disparate threads, which together explain the phenomenon? As Kuratko et al. (2015, p.3) maintain, "new opportunities for entrepreneurship theory...will be based on both expanding the contexts of entrepreneurship as well as a deepening of the existing theoretical approaches." The purpose of this paper is to expand the context by elaborating a series of illustrative candidate frameworks that validate the emergence of biosphere entrepreneurship.

\section{Candidate frameworks for a theory of biosphere entrepreneurship}

The entrepreneurial process is influenced by its context and thus entrepreneurial activity has changed over time [Baumol, 1990; Frederick et al., (2016), pp.10-13]. This paper maintains that Morris et al. (2001a, p.47) were three-quarters correct when they wrote: "Entrepreneurship is a meaningful concept at the individual, organisational, and societal levels, and the frameworks perspective is applicable at each of these levels." In the present age, entrepreneurship theory must also be applicable at fourth level: the realm of the Earth. Both theory and practice point us in that direction.

We begin with a general framework - Boulding's three spheres of human activity and proceed to finance and capital frameworks; allocation of entrepreneurial activity; risk and survival; value and disvalue; growth frameworks; socio-cultural frameworks; and finally entrepreneurial opportunity frameworks. These frameworks are chosen not because they represent an exhaustive list but rather because they illustrate and validate the emergence of biosphere entrepreneurship. 


\subsection{Three spheres of entrepreneurial activity}

A half-century ago, economist Kenneth Boulding (1996) penned the influential essay 'The Economics of the Coming Spaceship Earth', in which he posited three spheres of human activity: econosphere, sociosphere, and biosphere (see Figure 1). At the outside is the biosphere, which consists of all of the living and non-living things on Earth. Within the biosphere, the sociosphere is composed of all the people in a social system, all the roles they occupy. In Boulding's view, this was the realm of human information, knowledge, society, norms, social allocation, and culture. Finally, at the centre of this framework, we see the econosphere as all objects, people, and organisations involved in the system of exchange. From a material point of view (arrows in Figure 1), we see objects $(\mathrm{O})$ passing from the biosphere into the econosphere through the sociosphere in the process of production, and we similarly see two types of objects passing out of the econosphere back into the biosphere. One extracts biosphere value into the econosphere and returns it as zero or negative (-). The other views production passing from the econosphere into the biosphere as positive $(+)$. To Boulding, it was obvious that Earth was actually a closed, self-contained 'metabolism' with diminishing resources and no room for waste, what he called the 'spaceship economy'. In his view, the object was to increase positive value passing into the biosphere and minimise the zero or negative.

Predominant thinking positions entrepreneurial value creation in the econosphere and names it business or commercial entrepreneurship. In recent years, researchers have identified a second level of entrepreneurial activity - one that has an embedded social purpose and creates social value for the community, rather than personal and shareholder wealth, as business entrepreneurs do. Social entrepreneurship resides in the sociosphere (although subsequent writers have identified hybrid structural forms which mix business and social value creation) (Dees, 1998; Zadek and Thake, 1997; Austin et al., 2006). Using Boulding's framework as adapted, the third locus of entrepreneurial activity reveals itself. Can entrepreneurs create value in the biosphere, not only in the economy and community? Can we identify a class of biosphere entrepreneurs, in addition to business and social entrepreneurs? What are the hallmarks of this type of entrepreneurial activity that creates value for the planet rather than just society or the economy?

Figure 1 Boulding's three activity spheres (see online version for colours)

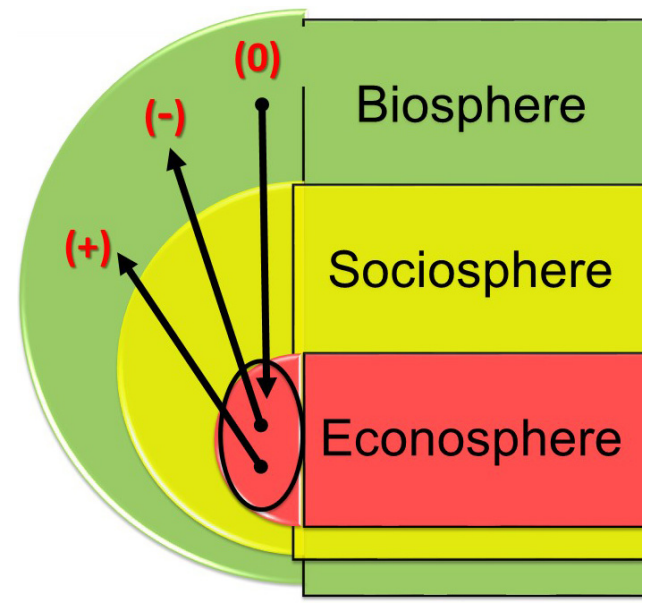




\subsection{Financial and capital frameworks}

Moving on, we can see that Boulding's three spheres also apply to entrepreneurial finance and capital. Traditional finance and capital frameworks explain the venture funding process through different stages of growth, from seed capital to IPOs (Aggestam, 2014; Brophy and Shulman, 1992; Erikson, 2002; Kuratko et al., 2015). Entrepreneurs need financial and manufacturing capital to create other goods or services (Sullivan and Sheffrin, 2003). Classical frameworks view entrepreneurial capital as money and manufacturing plants. They do not consider new forms of capital. We now need to look beyond the classical framework to examine new finance and capital frameworks that address entrepreneurial activity in the biosphere (Forum for the Future, n.d; Porritt, 2007; Tuazon et al., 2013). Here we examine two of them.

Figure 2 The five capitals framework within the biosphere, sociosphere and econosphere (see online version for colours)

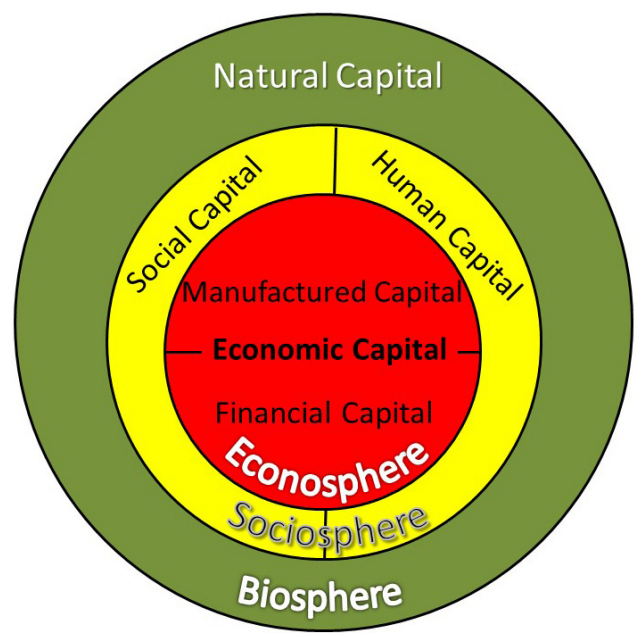

One is called the 'Five Capitals Framework' [derived from Boulding (1970, p.1, 11); Diesendorf and Hamilton, (1997)]. This framework shows that capital can arise from each of Boulding's spheres (see Figure 2):

- The econosphere yields finance capital and manufacturing capital. Financial capital, also known as 'money', is the core of what entrepreneurs use to leverage other resources. Manufactured capital is made up of physical goods (ironically known as 'the plant') such as machinery, vehicles, computers and so forth that contribute to production rather than being the output itself.

- The sociosphere contributes two forms of capital for entrepreneurs. Human capital refers to the knowledge, skills, intellectual outputs, motivation, and talent that we carry around inside us. We call this human resources or labour. Social capital refers to the collective value of social networks and relationships among people, and to the inclinations that arise from these networks to do things for each other.

- The biosphere (and here is the innovation) yields natural capital, or the stock of ecological systems that entrepreneurs use to create goods or services. Natural capital 
supplies entrepreneurs with a multitude of ecosystem services including carbon sequestration, waste detoxification, hydro-power, raw materials, food, and soil formation. Natural capital is different from other forms of capital in that it cannot be produced (only destroyed) by human activity. Well-managed, natural capital can be indefinitely sustainable.

Boulding's three spheres also relate to modern entrepreneurial financial measures, which have moved beyond 'profit' and 'shareholder value', and now takes into account the so-called triple bottom line (TBL) (Figure 3), a phrase coined by Elkington (1994, 1997). TBL performance measures examine all three spheres by analysing the three P's: planet (biosphere), people (sociosphere), and profits (econosphere).

Figure 3 Triple bottom line performance framework (see online version for colours)

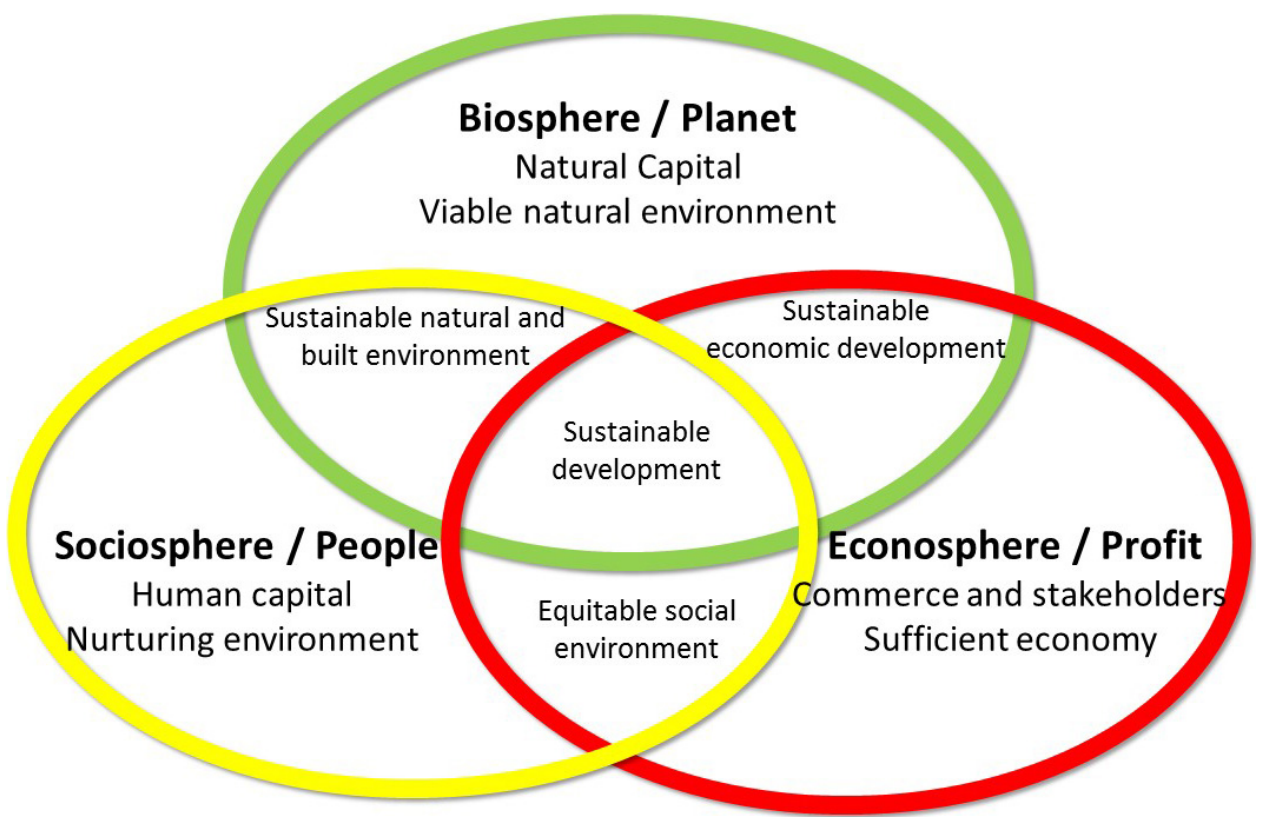

What distinguishes TBL from the previous classical capital/finance performance frameworks is that TBL looks beyond a firm's shareholders and includes Earth as a stakeholder. The "natural environment [is] the primary and primordial stakeholder of the firm" (Driscoll and Starik, 2004). A primordial stakeholder is any living thing that is influenced, either directly or indirectly, by the actions of business and social entrepreneurs. TBL uses Earth-monitoring performance measures such as life-cycle analysis; gap analysis, eco-efficiency ratios and measures; industrial ecology and supply chain linkages; emissions tracking; sources of greenhouse gas and reduction targets; and internal carbon dollar value.

In this section, we extended two financial and capital frameworks into the realm of the biosphere. We see that there is more to entrepreneurial capital than money, and more to entrepreneurial performance measures than shareholder value. 


\subsection{Allocation frameworks}

Now let us examine Baumol's allocation framework: 'productive, unproductive, and destructive'. Arguably the leading thinker of entrepreneurship and innovation since Schumpeter (1934), Baumol (1990, p.894) maintains that the allocation of entrepreneurial activity is socially determined and is heavily influenced by the relative payoff prospects. What mattered was not the number, or supply, of entrepreneurs to drive economic growth and innovation, but how society allocated their activity - whether or not they devoted their energies to creating 'productive' innovations that add to economic growth, or to 'unproductive' and 'destructive' activity, such as do fraudsters, property owners, rent-seekers, and criminal entrepreneurs. What mattered to Baumol was how some societies incentivise growth-producing entrepreneurs, while others incentivise unproductive or destructive entrepreneurs. For example, some economies reward entrepreneurs who do not contribute to growth, such as finding clever ways to win patronage from the state, creating monopolies, or engaging in criminal activity.

Let us take Baumol's three categories into new territory, namely into the biosphere, and imagine what he might have written if he had considered this. Would he have gone beyond his three categories and added a fourth kind of entrepreneurial activity, called 'annihilative', to describe entrepreneurs who plunder the planet?

Baumol begins by adding a new component to Schumpeter's well-known four-part framework [(1934), p.66, 1912] of how entrepreneurs use combinations of resources and technology to exploit the market. Schumpeter saw innovation resulting from:

1 a new good

2 a new production method

3 a new market

4 a new supply of raw materials. ${ }^{1}$ Baumol added a fifth category

5 non-value-creating activities, such as tax evasion, excessive litigation, and rent seeking, which he calls 'unproductive' entrepreneurship.

Baumol's fifth category means that the there is no overall value-gain - only redistribution of existing revenue streams to the benefit or detriment of one or another actor in the value chain. Following this argument, there is always a trade-off between innovation and growth (productive entrepreneurs) and redistributing existing wealth (unproductive rent-seekers) (Murphy et al., 1991). Baumol's point is that there is no use in increasing the supply of entrepreneurs. What matters is moving the allocation of entrepreneurs out of unproductive activities and into ones that are more productive, by changing prevailing rules and policies that govern payoffs of one entrepreneurial activity relative to another.

Note that the title of Baumol's article was 'Productive, unproductive, and destructive' [emphasis added]. Regrettably, Baumol did not elaborate much on destructive entrepreneurship. But Desai and Acs's 'Theory of destructive entrepreneurship' has helped us to fill in Baumol's gap. They point out that while "productive entrepreneurship [is] rent-creating, and unproductive entrepreneurship [is] rent seeking,...destructive entrepreneurship is rent-destroying." Destructive entrepreneurship has a negative effect on the economy and diminishes the inputs for production [Desai and Acs, (2007), p.6, 14]. 
Table 2 Allocation of productive, non-product, destructive, and annihilative entrepreneurship

\begin{tabular}{|c|c|c|c|c|}
\hline $\begin{array}{l}\text { Type of } \\
\text { entrepreneurial } \\
\text { activity }\end{array}$ & $\begin{array}{c}\text { Productive } \\
\text { entrepreneurship }\end{array}$ & $\begin{array}{c}\text { Unproductive } \\
\text { entrepreneurship }\end{array}$ & $\begin{array}{c}\text { Destructive } \\
\text { entrepreneurship }\end{array}$ & $\begin{array}{c}\text { Annihilative } \\
\text { entrepreneurship }\end{array}$ \\
\hline Stereotype & $\begin{array}{l}\text { Value-creating } \\
\text { Hero }\end{array}$ & Robber of value & $\begin{array}{l}\text { Exploiter of } \\
\text { value }\end{array}$ & $\begin{array}{l}\text { Plunderer of } \\
\text { Value }\end{array}$ \\
\hline $\begin{array}{l}\text { How does the } \\
\text { entrepreneur } \\
\text { treat rent } \\
\text { seeking? } \\
\text { Defined as } \\
\text { payment in } \\
\text { excess of the } \\
\text { costs needed to } \\
\text { produce. }\end{array}$ & $\begin{array}{l}\text { Rent-creating. } \\
\text { Pursues } \\
\text { opportunity } \\
\text { within prevailing } \\
\text { rules. } \\
\text { Contributes to } \\
\text { collective value } \\
\text { and to the } \\
\text { capacity to } \\
\text { produce } \\
\text { additional value. }\end{array}$ & $\begin{array}{l}\text { Rent seeking. } \\
\text { Adds little value } \\
\text { to economy. } \\
\text { Side-steps } \\
\text { regulation, } \\
\text { evades taxes, } \\
\text { lobbies for } \\
\text { influence, } \\
\text { acquires } \\
\text { monopoly rights, } \\
\text { establishes } \\
\text { protective } \\
\text { guilds, executes } \\
\text { legal but hostile } \\
\text { takeovers. }\end{array}$ & $\begin{array}{l}\text { Rent-destroying. } \\
\text { Destroys value } \\
\text { but recovery is } \\
\text { possible. } \\
\text { Employs fraud, } \\
\text { corruption, } \\
\text { bribery, IP } \\
\text { piracy, litigation, } \\
\text { theft, criminal } \\
\text { entrepreneurs, } \\
\text { drug dealing, } \\
\text { prostitution, } \\
\text { racketeering, } \\
\text { blackmailing. }\end{array}$ & $\begin{array}{l}\text { Rent } \\
\text { annihilating. } \\
\text { Recovery is } \\
\text { impossible; } \\
\text { damage is } \\
\text { irreversible. } \\
\text { Irreparable value } \\
\text { destruction } \\
\text { through toxic } \\
\text { waste, } \\
\text { destruction of } \\
\text { ecosystem } \\
\text { services, ecocide } \\
\text { of species. }\end{array}$ \\
\hline $\begin{array}{l}\text { Does the } \\
\text { entrepreneur } \\
\text { capture rents? }\end{array}$ & $\begin{array}{l}\text { Yes. Increases } \\
\text { one's share of } \\
\text { existing wealth } \\
\text { while creating } \\
\text { new wealth for } \\
\text { others. }\end{array}$ & $\begin{array}{l}\text { Appropriates } \\
\text { rents for one's } \\
\text { own use. }\end{array}$ & $\begin{array}{l}\text { Destroys rents } \\
\text { but recovery is } \\
\text { possible. }\end{array}$ & $\begin{array}{l}\text { Destroys rents } \\
\text { but damage is } \\
\text { irreparable and } \\
\text { impossible. }\end{array}$ \\
\hline Value creation & Positive & $\begin{array}{l}\text { Unaffected, } \\
\text { redistributed }\end{array}$ & $\begin{array}{l}\text { Negative. Value } \\
\text { lowered. }\end{array}$ & $\begin{array}{l}\text { Toxic. Disvalue } \\
\text { creation }\end{array}$ \\
\hline $\begin{array}{l}\text { Effect on the } \\
\text { biosphere }\end{array}$ & $\begin{array}{l}\text { Adds value to } \\
\text { labour, capital } \\
\text { and natural } \\
\text { resources. } \\
\text { Respects and } \\
\text { adds to the } \\
\text { commons. }\end{array}$ & $\begin{array}{l}\text { Redistributes } \\
\text { land, labour and } \\
\text { capital to } \\
\text { favoured actors. }\end{array}$ & $\begin{array}{l}\text { Diminishes land, } \\
\text { labour and } \\
\text { capital, extracts } \\
\text { natural resources } \\
\text { without } \\
\text { replenishing. }\end{array}$ & $\begin{array}{l}\text { Annihilates land, } \\
\text { labour and } \\
\text { capital. Makes } \\
\text { natural resources } \\
\text { unusable, sets } \\
\text { off negative } \\
\text { chain reactions. }\end{array}$ \\
\hline $\begin{array}{l}\text { Example: } \\
\text { fishing }\end{array}$ & $\begin{array}{l}\text { Farm fishing; } \\
\text { hatchery, tuna } \\
\text { ranching }\end{array}$ & $\begin{array}{l}\text { Ocean fishing } \\
\text { treaties; factory } \\
\text { ships. }\end{array}$ & $\begin{array}{l}\text { Dynamite } \\
\text { fishing }\end{array}$ & $\begin{array}{l}\text { Drag-net, bottom } \\
\text { trawl, dredge }\end{array}$ \\
\hline $\begin{array}{l}\text { Example: tree } \\
\text { harvesting }\end{array}$ & $\begin{array}{l}\text { Cut and replant } \\
\text { forestry }\end{array}$ & Contract forestry & $\begin{array}{l}\text { Clear-cut } \\
\text { harvesting }\end{array}$ & $\begin{array}{l}\text { Burning of the } \\
\text { rainforest to } \\
\text { plant cash crops }\end{array}$ \\
\hline
\end{tabular}

To these three categories - productive, unproductive, and destructive - in the present era of biosphere entrepreneurship, the present author proposes a fourth category: 'annihilative entrepreneurship' (see Table 2). The difference lies in whether the resulting destruction of rents is recoverable or not. Productive entrepreneurs capture rents to the benefit of further growth. Unproductive entrepreneurs (think fraudsters) appropriate rents without adding to collective value. Destructive entrepreneurs (think criminals) destroy rents but recovery from this calamity is still possible. Annihilative entrepreneurs (think ivory hunters) destroy rents, and the damage is catastrophic and irrecoverable. Desai and 
Acs (2007) proposed a framework showing the principal differences between productive, unproductive, and destructive entrepreneurship, to which the present author has added the far-right hand column in Table 2.

These factors of allocation of value in entrepreneurship are summarized in Table 3.

Table 3 Extending Baumol's types of entrepreneurs

Productive entrepreneurs capture rents ethically through innovation and also benefit further growth.

Unproductive entrepreneurs unethically appropriate rents without adding to collective value through devious use of the legal system or through organised crime. They divert rents through payoffs, litigation, takeovers, and tax evasion.

Destructive entrepreneurs destroy rents but this destruction may be recoverable.

Annihilative entrepreneurs destroy rents, and the damage is catastrophic and irrecoverable.

In this section, we saw that the allocation of entrepreneurial activity is just as important as the supply of entrepreneurs. To Baumol's (Schumpeter's) 'productive, unproductive, destructive' framework, we added 'annihilative' to indicate that some entrepreneurial activity results in the irrecoverable destruction of rents.

\subsection{Entrepreneurial risk and survival frameworks}

We now move on to another framework that validates the emergence of biosphere entrepreneurship as a construct and lends itself to theory building. Throughout the literature, researchers have categorised entrepreneurial risks that affect an entrepreneur's calculated success or failure, or better said, predict the demise or success of a venture due to outside factors (see for example, Baggs, 2005; Esteve-Pérez and Mañez-Castillejo, 2008; Lewis and Churchill, 1983; Stearns et al., 1995). Janney and Dess (2006) listed financial, career, family, social, and psychic risks. Ebben (2005) added market, operational, business model, financial, and opportunity risks. Vonortas and Kim (2015, p.123) listed technology, timing, competition, market, and intellectual property risks. Mason and Harrison (2004, pp.317-318) added management, agency, market, technology, valuation, project, growth, and timing risks.

The present era presents far graver risks. What is the role for entrepreneurs in a climate change-battered world, one in which some might perish from the effects of climate change while others, living in less vulnerable areas, essentially do nothing to prevent their annihilation? (Klare, 2012, 2017). To date, entrepreneurship research has failed to address risks at the existential level - ones that threaten the entire future of humanity.

To show this, we extend Bostrom's (2013) risk framework (see Figure 4) mapped against entrepreneurial action. Across the x-axis, we measure severity of risk from the:

1 imperceptible

2 endurable but not ruinous

3 crushing, loss of life

4 hellish and life-extinguishing types of risk. 
Up the y-axis, we can depict the scope of risk from the:
a personal
b local
c global
d trans-generational
e pan-generational.

Some risks affect humanity across multiple generations through such dangers as nuclear war, global tyranny, disappearance of the ozone layer, destruction of culture, pandemics, and climate change. Have entrepreneurs, for example, taken into account the above-cited Stern Review on the Economics of Climate Change, which estimates a 9.5\% risk of human extinction by 2100 (Stern, 2006, Chapter 2, technical appendix, 47)? Estimates of 10-20\% extinction risk are fairly common (Bostrom, 2013; Bostrom and Cirkovic, 2011; Cotton-Barratt et al., 2015; Sandberg and Bostrom, 2008).

Figure 4 Risk and scope for entrepreneurial action (see online version for colours)

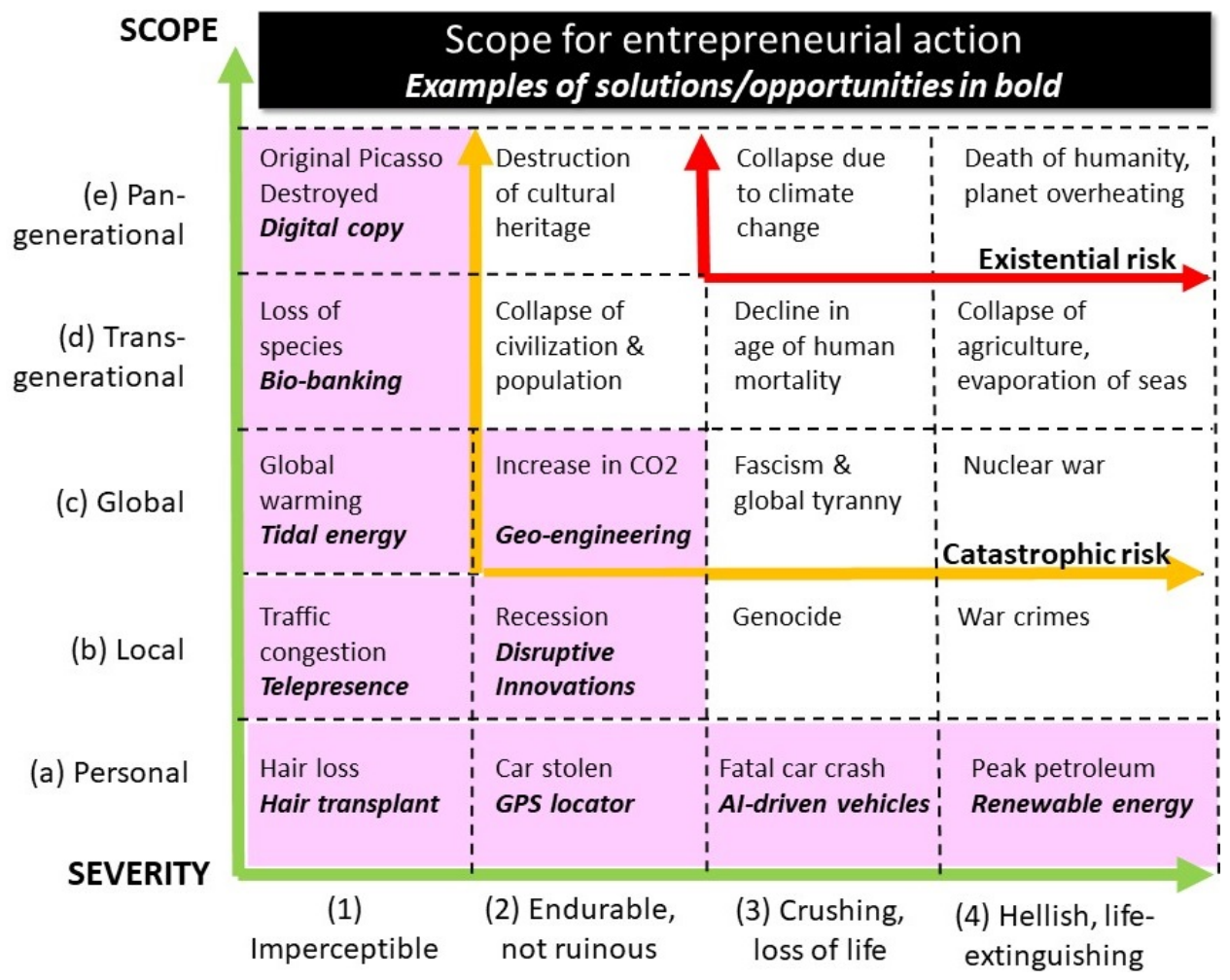

How do these catastrophic and existential risks affect entrepreneurial action? What actions can entrepreneurs take to adapt to or mitigate these risks? We can see (Figure 4 in the shaded areas) that entrepreneurs have been able to address some of the risks and 
calamities that face us by taking advantage of opportunities and designing solutions (in bold italics) at the personal, local and global levels, especially at the level of 'imperceptible' or 'endurable' severity. However, as we move toward the upper right, entrepreneurial actions have had less to offer, with geo-engineering entrepreneurs ${ }^{2}$ perhaps the first to cross into action on global catastrophic risk. The questions remain open whether entrepreneurs can address these higher-order global catastrophic risks not to mention crushing and hellish existential risks.

Entrepreneurship research has yet to come to grips with existential risks. Some believe that entrepreneurial ventures can "contribut[e] to human wellbeing and the functioning of ecological systems....adapting human activities to correspond with that aspired future" [Parrish, (2007), p.3, 37). Yet entrepreneurs themselves frequently act as if no crisis existed. Indeed, little of the extant literature examines how entrepreneurs can affect the conditions of human survival. Nor does it value the kind of "enterprise that recognizes the necessary interdependence of human development, economic activity and our place on Mother Earth" [Campbell, (2008), p.165].

Despite the dearth of writing on existential risks in entrepreneurship research, the field of evolutionary economics has treated the subject extensively (see Gowdy, 2013; Mulder and Van Den Bergh, 2001; Safarzyńska and Van Den Bergh, 2010; Van Den Bergh, 2007a, 2007b; Van Den Bergh and Gowdy, 2000). Our own field - the exceptions being Potts et al. (2010) and Breslin (2008) - has been poor in mapping entrepreneurial action against energy and material flows, system resilience, and co-evolutionary processes, and especially how entrepreneurship is constrained by and affects Earth's carrying capacity,

In sum, the expectation of existential risks should encourage entrepreneurs to open up new opportunity spaces (Boons and Wagner, 2009). Entrepreneurial action can adapt to or mitigate an environmental stressor rather than be limited by it (Rammel, 2003). In states of uncertainty, entrepreneurs recognise negative environmental effects which, when revealed, stimulate entrepreneurial activity that may mitigate such effects (Potts et al., 2010). In this section, we looked at whether entrepreneurs can move beyond traditional risks to address existential risks that threaten humanity. The scope for entrepreneurial action goes beyond endurable risks and must now consider crushing and life-threatening risks.

\subsection{Entrepreneurial value and disvalue creation frameworks}

Critical to the present analysis is how we as societies and economies view value within the context of opportunity and allocation of entrepreneurial activity. Our literature has evolved in the ways it views value creation. Early authors identified value as the purposeful initiating, maintaining, or aggrandising of profit [Cole, (1959), p.7]. Anderson $(1998$, p.137) argued that if we reduce entrepreneurship to its essence, we can see that what entrepreneurs do is to create and extract value from an opportunity. Today, scholars see growth as just as important as value creation (Carland et al., 1984; Davidsson et al., 2006; Davidsson, 1989; Gartner, 1990; Venkataraman, 1997).

Yet current global crises have brought to light the myopia in that thinking. We have come to realise that value creation has an evil twin, disvalue creation; and that value creation can occur without regard to the sustainable extraction of finite resources (see 
Table 4). Value and its opposite, disvalue, are influenced by the context of the economy, society, and the planet, as well as by the incentives given to entrepreneurs (Baumol, 1990; Steyaert and Bouwen, 1997; Anderson and Smith, 2007; Fletcher, 2006; Jack and Anderson, 1998; Gray et al., 2014; Blundell et al., 1995). Recent work has contrasted value creation with disvalue creation, also referred to as the creation of 'negative worth' (Jolink and Niesten, 2015; Schaltegger et al., 2016). This contrarian position harkens back to Schumacher's $(1973,2011)$ Small is Beautiful, which argued for 'economics as if people mattered'. Humans use one and a half Earths worth of biocapacity every year. Schumacher might equally have said "entrepreneurship as if the planet mattered." Overall, entrepreneurship theory has largely overlooked the negative externalities of opportunistic entrepreneurship. In Table 4, we depict entrepreneurial value and disvalue. The three spheres of human activity (from Boulding, above) and their intersections define seven types of value creation (see also Figure 5), each with its own objectives, processes, outputs, and outcomes. ${ }^{3}$ Let us compare the value creation framework of Cohen et al. (2008, pp.109-116) with an invented disvalue creation framework ${ }^{4}$.

Table 4 Seven nodes of value and disvalue creation

\begin{tabular}{|c|c|}
\hline Value creation & Disvalue creation \\
\hline $\begin{array}{l}\text { Utilitarian performance of the } \\
\text { econosphere: cash flow, dividends, } \\
\text { royalties, profit, return, competitive } \\
\text { advantage }\end{array}$ & $\begin{array}{l}\text { Dysfunction of the econosphere: fraud, corruption, } \\
\text { bribery, IP piracy, litigation, theft, criminal } \\
\text { entrepreneurs, drug dealing, prostitution, } \\
\text { racketeering, blackmailing. }\end{array}$ \\
\hline $\begin{array}{l}\text { Socio-efficiency (performance-promise): } \\
\text { quality, strategy, market entry, customer } \\
\text { retention, alliances, readiness for harvest }\end{array}$ & $\begin{array}{l}\text { Depredation (dysfunction-abrogation): dishonesty, } \\
\text { market barriers, locking in customer, oligarchy, } \\
\text { hostile take-over. }\end{array}$ \\
\hline $\begin{array}{l}\text { Promise of the sociosphere: responsibility, } \\
\text { legitimacy, equity, involvement, } \\
\text { interactions, fair-trade. }\end{array}$ & $\begin{array}{l}\text { Abrogation of the sociosphere: irresponsibility, } \\
\text { illegitimacy, inequity, disinvolvement, } \\
\text { segregation, monopoly trade. }\end{array}$ \\
\hline $\begin{array}{l}\text { Stewardship (promise-perpetuity): } \\
\text { consumer education, recycling, re-use, } \\
\text { protection, quality of life }\end{array}$ & $\begin{array}{l}\text { Exploitation (abrogation-impermanence): } \\
\text { Consumer greenwashing, wasteful one-use, harm, } \\
\text { environmental crime. }\end{array}$ \\
\hline $\begin{array}{l}\text { Perpetuity of the biosphere: restoration, } \\
\text { emissions reduction, waste management, } \\
\text { design. }\end{array}$ & $\begin{array}{l}\text { Impermanence of the biosphere: destruction, } \\
\text { emissions increase, waste, disorder. }\end{array}$ \\
\hline $\begin{array}{l}\text { Eco-efficiency (perpetuity-performance): } \\
\text { materials use, energy management, clean } \\
\text { production, green development. }\end{array}$ & $\begin{array}{l}\text { Malfeasance (impermanence-dysfunction): } \\
\text { materials burning, energy mismanagement, } \\
\text { contamination, and pollution. }\end{array}$ \\
\hline $\begin{array}{l}\text { Value (performance-promise-perpetuity): } \\
\text { ethics, innovation, development, } \\
\text { effectiveness, survival. }\end{array}$ & $\begin{array}{l}\text { Disvalue (dysfunction-abrogation-impermanence): } \\
\text { corruption, dishonesty, immorality, stasis, } \\
\text { stagnation, retrogression, unproductivity, } \\
\text { existential risk, annihilation. }\end{array}$ \\
\hline
\end{tabular}

Source: Adapted from Cohen et al. (2008)

The learnings in this section are that entrepreneurs, as they seek and recognise opportunities, are sometimes driven to create disvalue by unproductive, destructive, and annihilative motivations (see Baumol, 1990, above). Human beings routinely create value and disvalue, whereas nature always creates value (Balazs, 2013). Disvalue means negative value creation. In the end, some entrepreneurs choose climate-resilient pathways that traverse opportunity space and add value to the biosphere. Others with different 
motivations and allocative factors produce disvalues, namely deleterious effects on the economy, society and environment.

Figure 5 Entrepreneurial value and disvalue creation

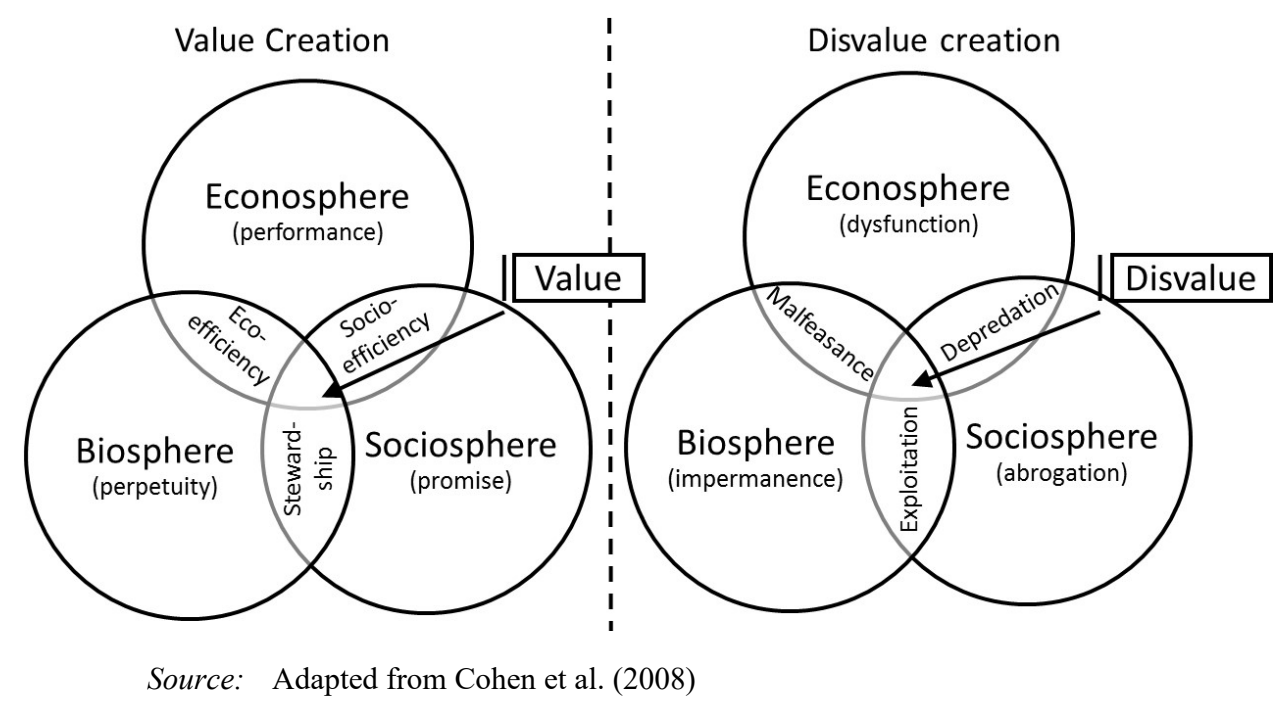

\subsection{Entrepreneurial growth frameworks}

Now we go on to examine a growth framework that relates to biosphere entrepreneurship. The classical economic growth paradigm (Rostow, 1991; Solow, 1956) sought to optimise resources within an equilibrium environment. Given that the classical paradigm does not well account for the wanton consumption of natural resources, nor the impact of technology, we review this framework within the context of our present enterprise.

In our research tradition, Schumpeter challenged the classical growth paradigm of a stable state of balanced growth by introducing what he called the disruptive entrepreneur. As Schumpeter saw it, a normal, healthy economy was not balanced, was not in equilibrium. Rather it was constantly being 'disrupted' by innovation. This framework draws upon what Kondratieff (1922) and Schumpeter (1939) described as 'long waves', or business cycles driven by clusters of industries/technologies that introduced new sets of innovations (see Figure 6). The entrepreneur's role was to drive this process of creative destruction and accelerate the ever-shortening cycles, thus allowing the economy to renew itself and bound forward and upwards [The Economist, 1999; Schumpeter, (1950), pp.80-86]. Schumpeter (1942, p.83) said it is "the same process of industrial mutation - if I may use that biological term - that incessantly revolutionizes the economic structure from within, incessantly destroying the old one, incessantly creating a new one. This process of creative destruction is the essential fact about capitalism."

To relate this to biosphere entrepreneurship, let us make one small change to Schumpeter's (Kondratieff's) theory of long cycles of industrial innovation. We simply re-label the y-axis. Schumpeter had called it 'Innovation'; here we change it to 'Stress on Earth's carry capacity', and make no other changes. We see that each industrial cycle increases the burden of stresses on Earth's carrying capacity and results in a 'peak curve' followed by demise and collapse. This corresponds to Hubbert's peak resource theory, 
which predicts the depletion of various natural resources (Black, 2014; Gray, 2015; Hubbert, 1982). A peak curve applies to any resource that is harvested faster than it can be replaced. Hubbert used it initially to measure the end of finite resources, such as coal, oil, natural gas and uranium, but the theory is now used with other depleting resources such as ecosystem services in the biosphere (Bostan et al., 2012; Franchetti and Apul, 2012; Holmgren, 2012).

Figure 6 Kondratieff/Schumpeterian growth waves, substituting innovation for carrying capacity

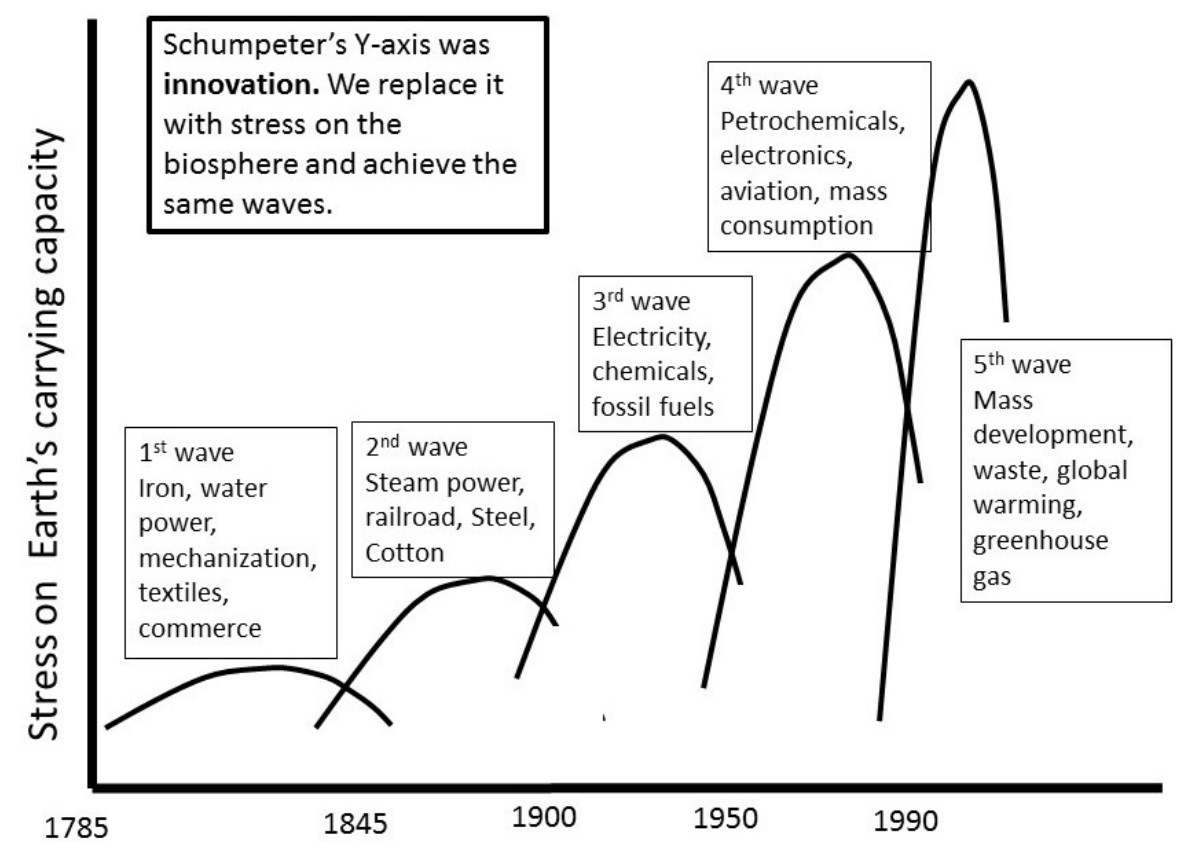

To recover lost resources and return to equilibrium growth, some researchers have proposed the exact opposite to the classical framework. The 'de-growth' framework confronts traditional ideas of the desirability of incessant growth, consumerism and capitalism (Andersson and Eriksson, 2010; Buch-Hansen, 2014; Kallis, 2011; Klitgaard and Krall, 2012; Victor, 2012; Assadourian, 2012). De-growth is defined as an "equitable downscaling of production and consumption that increases human well-being and enhances ecological conditions" [Schneider et al., (2010), p.512]. In this view, entrepreneurs find opportunities in decoupling resource consumption from economic growth. The seekers of de-growth spot opportunity in resource caps, sanctuaries, infrastructure moratoria, eco-taxes, work sharing and reduced working hours. We can also imagine opportunities in eco-villages and co-housing, cooperative production and consumption, a sharing economy, and community-issued currencies. De-growth need not mean a decrease in wellbeing, or indeed of individual profit.

Braungart and McDonough (2002) challenged entrepreneurs to envision a 're-growth framework' without waste and poisons, a world in which materials are recycled/up-cycled from the economy in and out of the biosphere (see Figure 7). 
Figure 7 Re-growth framework of McDonough and Braungart (see online version for colours)

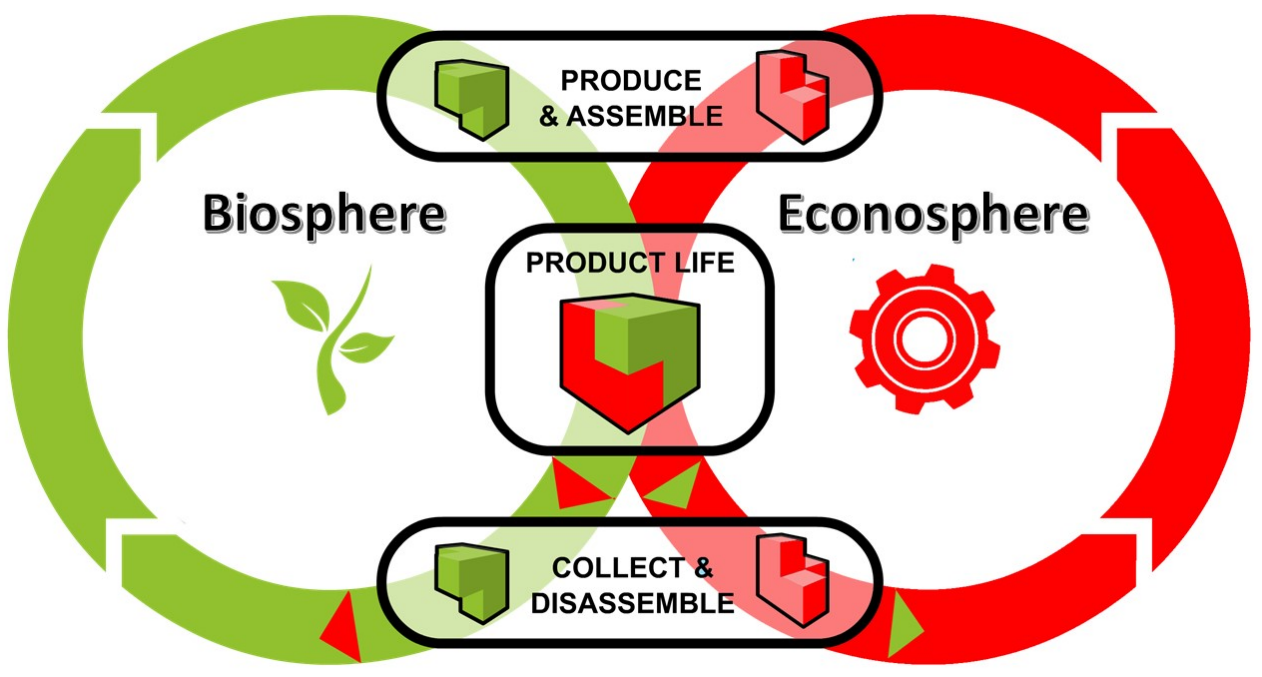

The key to re-growth is making the economy work for the environment instead of against it, which has a deleterious impact in terms of pollution and is expensive since new materials have to be manufactured from scratch every time. In the 'cradle-to-cradle' framework, green 'nutrients' feed into the production process. They can be continuously useful (recyclable) over repeated production without losing their integrity or quality. Some will ultimately be 'down-cycled' into lesser products, and will finally become waste. Others will be up-cycled into higher value-added products. Through design and manufacturing techniques, entrepreneurs can build products that can be fully re-grown for the biosphere (natural capital) or re-gained for the econosphere (manufactured capital).

In this section we have examined growth, de-growth, and re-growth frameworks as they relate to biosphere entrepreneurship. The classical growth paradigm suffers for its requirement of equilibrium and its need for ever-newer technology, and particularly because it does not account for the heedless exploitation of resources without a thought to replenishment. The Schumpeter/Kondratieff framework, with one change to its y-axis, accounts for diminishment of natural capital and relates well to 'peak resource' theory. We then addressed the novel de-growth and re-growth frameworks as they relate to entrepreneurial action. Using these extensions to the canonical growth framework, we can envision a world in which entrepreneurs could take advantage of reversing growth through up-cycling of materials and returning value to the biosphere.

\subsection{Socio-cultural frameworks}

Many biosphere-consequential behaviours are strongly influenced by external factors (Gardner and Stern, 1996; Stern, 1999). Within entrepreneurship research, this framework is unsuitably called the environmental framework because it refers to factors in the surrounding context (Alvarez and Urbano, 2012; Dubini, 1987; Edelman and Yli-Renko, 2010; Hayton et al., 2002; Nguyen et al., 2014; York and Venkataraman, 2010). But for reasons of clarity vis-à-vis the present topic, we will call it the 
socio-cultural framework, as many have done (Begley and Tan, 2001; Majidand Yaqun, 2016; Shivani et al., 2006; Thornton et al., 2011; Toledano and Ribeiro-Soriano, 2011).

Socio-cultural frameworks traditionally look at factors, conditions and influences external to the entrepreneur that affect the emergence of a new venture. This refers to phenomena such as social and cultural beliefs, altruism, behaviour, lifestyles, religion, family, education and social conditioning (Van de Ven, 1993). Prominent examples of this framework include Hofstede's (1984) cultural dimensions model, and Trompenaars and Hampden-Turner's (1998) human-nature dimensions. The question thus arises whether there are socio-cultural factors that influence the emergence of biosphere entrepreneurs. While work is being done on the impact of socio-cultural factors on social entrepreneurs (Koe et al., 2012; Majid and Koe, 2012; Shivani et al., 2006; Thornton et al., 2011), nothing has yet been written on the impact of these factors on biosphere entrepreneurs.

While we could and should take each of these socio-cultural phenomena and map them against biosphere entrepreneurship, due to lack of space, we must leave that to others. However, given some empirical evidence of the relationship (Nordlund and Garvill, 2003; Schultz and Zelezny, 1999, 1998), let it suffice for the present task to examine one socio-cultural framework, that of entrepreneurial altruism, and its relationship to the biosphere (see Figure 8).

Figure 8 Framework of the socio-cultural aspect of biospheric altruism (see online version for colours)

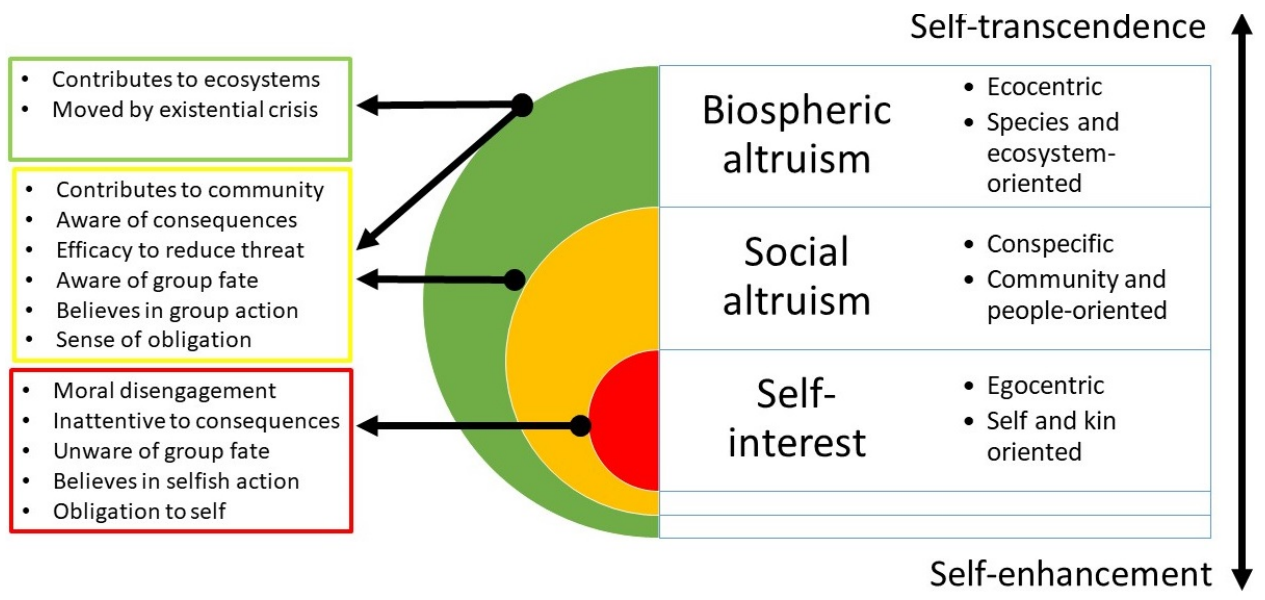

History reveals that there are those entrepreneurs who took advantage of the instrumental value of Earth's resources rather than cherishing and replenishing their intrinsic value. Again, drawing upon Boulding's (1996) three activity spheres, at the base in the econosphere we have self-interested entrepreneurs who seek economic expediency and exploit the environment with impunity. We call this the egocentric approach. At the top we have biosphere entrepreneurs who seek intrinsic value, namely to "preserve the integrity, stability, and beauty of the biotic community" [Leopold, (1970), p.18]. We will call this the ecocentric approach. In between these two, we have conspecific entrepreneurs, also known as social entrepreneurs, namely those who seek to benefit members of the same species and community. 
Drawing upon climate change sociology and particularly values-beliefs-norms (VBN) theory (Dietz et al., 2005; Stern, 2000; Stern et al., 1999; Zehr, 2015), let us examine the biospheric altruism framework more closely. At the bottom, we have the self-maximising egocentric entrepreneurs seeking benefit for self and kin, who are inattentive or ignorant of the consequences on society or the biosphere, and who may suffer, as Bandura (1986, 2001) and Bandura et al. (1996) suggest, from a 'moral disengagement' that harms the biosphere. Do these entrepreneurs structure their actions so they appear less harmful, shift accountability to others, or shift blame to the victims? Or is it, as Shepherd et al. (2013, p.1252) posit, that, in conditions of low self-efficacy and high perceived resource-scarcity, entrepreneurs use moral disengagement to adjust their values in to neutralise their feelings of harming the planet?

Beyond self-interest we have social altruism, where an entrepreneur reduces his own social fitness (in the Darwinian sense) while increasing another's fitness in the expectation that the other will act similarly at a later time (Trivers, 1971). Human cooperation and benevolence can be understood as "resulting from networks of indirect reciprocity" [Alexander, (1987), pp.3-20]. In this realm, we have the social entrepreneurs who move beyond self-interest to create value for their conspecifics and the broader community. At this level, entrepreneurs are motivated to add value to the community.

Finally, we have biospheric altruism, where entrepreneurs go beyond individual self-interest and possibly even beyond community benefit to add value to ecosystems (Dietz et al., 2005; Stern and Dietz, 1994). These entrepreneurs launch ventures that contribute to the planet and to ecosystem services. Biosphere entrepreneurs are motivated by an altruism to support ecological resilience by adding value to the biosphere.

In this section, we have used altruism as one example to map the relationship of socio-cultural factors to biosphere entrepreneurship. The main difference is where the 'value-add' (dividend) goes. Does it go into one's pocket or into the social community, as business and social entrepreneurs might do, respectively? Or is there a third category of biosphere entrepreneurs affected by external socio-cultural factors who prefer above all else to add value to natural capital? Other researchers may find this a fecund area in mapping other socio-cultural factors.

\subsection{Entrepreneurial opportunity frameworks}

Finally, and not least important, we examined two opportunity frameworks. Opportunity is so fundamental to entrepreneurship that for centuries understanding it has been one of the primary preoccupations of our research. Cantillon's entrepreneur [Hébert and Link, (2009), pp.7-19; Cantillon, (2001), p.1755] identified opportunities as market discrepancies seeking a new point of equilibrium. Schumpeter's (1934) entrepreneur disrupted existing markets and through opportunities created new ones. Kirzner (1985) placed emphasis on the entrepreneur's alertness to opportunities 'out there' waiting to be discovered. Attention has also focused on social opportunities, different from economic opportunities seeking to satisfy needs not satisfied by the market (Phills et al., 2008). In the end, identifying and shaping opportunity is so central to entrepreneurs that Shane and Venkataraman (2000, p.218) defined entrepreneurship as "how, by whom, and with what effects opportunities to create future goods and services are discovered, evaluated, and 
exploited." Indeed, many quip that entrepreneurs never waste a good crisis because they recognise opportunities where others see chaos or confusion (Dagnino and Mariani, 2007; Dimov, 2011; Gielnik et al., 2012; Tang et al., 2012). Entrepreneurs seek 'opportunity spaces' (Schindehutte and Morris, 2009; crediting De Landa, 1997). This could be no truer than in the present age when entrepreneurs face the existential threat of climate change and global warming.

Each of these entrepreneurial concerns - market discrepancies, disruption, alertness, and social innovation - has found its 'opportunists' within biosphere entrepreneurship. Cantillon's biosphere entrepreneurs are seen in such arenas as emissions trading, biodiversity offsets, payments for ecosystems services and reducing emissions from deforestation and forest degradation. Schumpeter's disruptors see opportunities in biobanking, bioprospecting, carbon sequestration technologies, geo-engineering, species banking, and virtual water trade. Kirzner's alertness entrepreneurs are bountiful in climate

change-induced problems of population (aging, youth, overpopulation), water (pollution, sanitation), food (protein/water consumption ratio, drought resistant strains), fossil fuels (clean energy, emissions control), and biodiversity (aquaculture, genetic diversity, ecosystem brokering, ecotourism). Finally, social opportunity entrepreneurs have launched new forms of community planning, fair trade, habitat conservation, labour standards, and microfinance.

Figure 9 Biosphere opportunity space framework (see online version for colours)
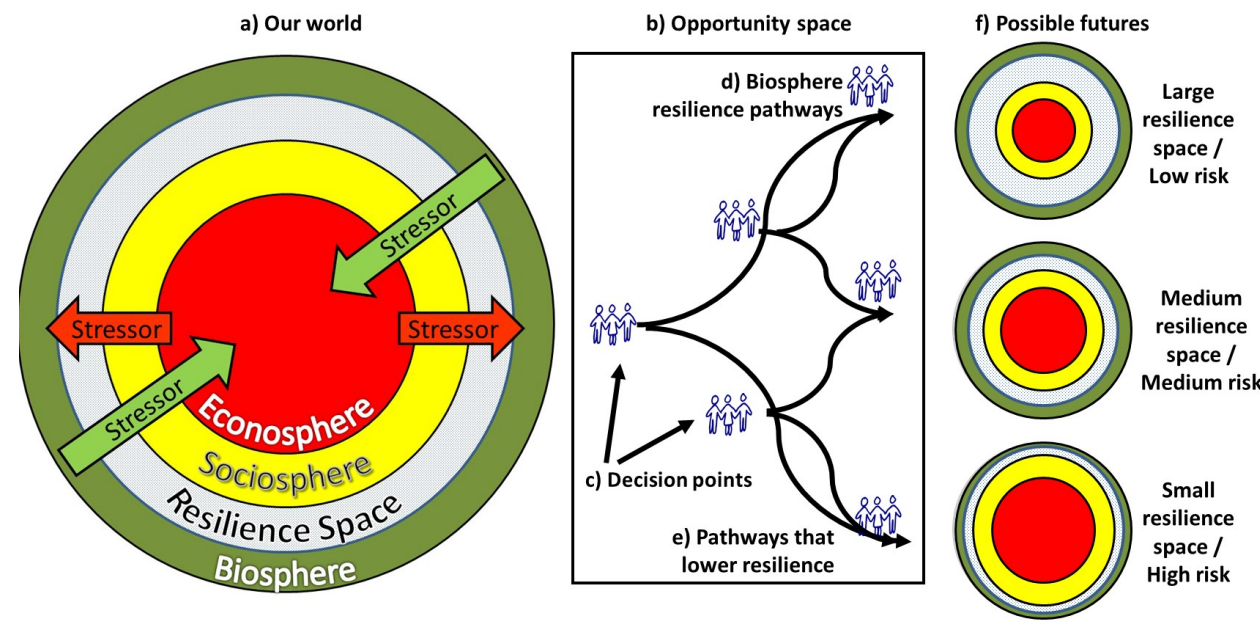

By reconciling and merging these frameworks, we arrive at the biosphere opportunity framework [adapted from Field et al., (2014), p.29] (see Figure 9). Biosphere opportunity spaces are arenas in which entrepreneurs identify opportunities to create value for a more resilient planet. Opportunity spaces are pressure points created by both the physical and social worlds and reveal the gaps, market failures, unmet needs of the Planet.

Narrating this framework from left to right, our world (a) is threatened from the outside by biophysical stressors, such as climate change and degradation of ecosystems; and from the inside by social and economic stressors, such as unrestrained economic growth, exploitation with impunity, population increase, poverty and inequality. These 
stressors expand and contract the resilience space (hatched areas), which is Earth's capacity to become strong and healthy, and to recover. Entrepreneurs operate within an Opportunity Space (b) where they face multiple decision points (c) and pathways (d) and (e). Some pathways lead to greater biosphere resilience (d) while other pathways (e) lead to lower resilience. These pathways produce different possible futures (f) for the planet, each with differing sizes of resilience space - small, medium, and large (hatch areas). Entrepreneurs take advantage of these pathways and exploit routes to market in which they act (or fail to act), or in which they manage (or fail to manage) risks related to the planet's resilience.

Figure 10 Natural step framework: narrowing margin for entrepreneurial opportunity (see online version for colours)

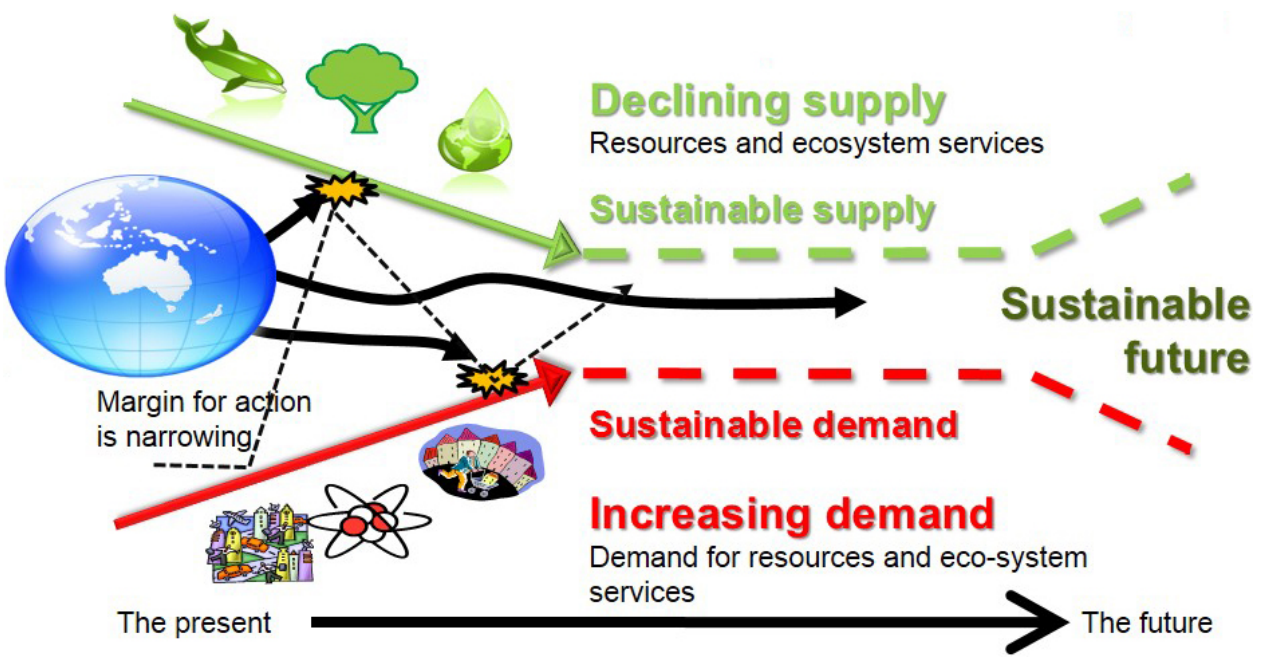

A second entrepreneurial opportunity space framework has been called 'The Natural Step' (see Figure 10) (Alexius and Furusten, 2013; Bradbury and Clair, 1999; Herbertson and Tipler, 2006; Holmberg, 2006; Holmberg et al., 1996; Martin and Schouten, 2014; Nattrass and Altomare, 1999, 2013). Imagine looking at a giant funnel on its side. The upper wall represents declining supply, which we hope will reach a sustainable equilibrium of available resources and the ability of the ecosystem to continue to provide them. The lower wall is increasing demand, which we hope will reach a sustainable equilibrium between demand and the ecosystem's ability to create them. The things we need to survive food, clean air and water, productive topsoil and others are in decline while the demand for them is increasing, which leads to a narrowing space for action and opportunity (see Figure 10). Meanwhile, as the funnel narrows there are fewer options and less room to maneuver, with actions bumping against the wall (blotches). The entrepreneurial opportunity space is that narrowing passage path toward future sustainability.

To summarise this section, we have reviewed entrepreneurial opportunity frameworks and reconciled them, showing paths that entrepreneurs can choose toward a sustainable and more resilient future. The basic learning is that there is narrowing scope for entrepreneurial action as the biophysical and socio-economic stressors reduce Earth's resilience as well as our collective capacity to help the planet recover. During the 
historical transition from entrepreneurship based on extraction of resources with impunity to value-adding to the biosphere, entrepreneurs must address the complexity and the dynamics of ecosystems in relation to social and economic activity. In the face of technological change, the uncertainty of consumer expectations, and the unpredictability of new regulations, entrepreneurs must learn not to violate conditions that systematically undermine Earth's capacity to meet present and future needs of humanity [Norton, (2012), 167].

\section{Toward a theory of biosphere entrepreneurship}

Taking the frameworks developed above, we now advance a synthesis. In the era of industrial entrepreneurship, from the nineteenth century through to the new millennium, entrepreneurs were not obliged to consider the environment in their planning and design. They focused on extraction of resources with little regard to their replenishment and on distribution without regard to distance. The history of entrepreneurship shows that entrepreneurs were not typically oriented towards the prevention of negative effects, to the reversal of degradation, or to net improvement in the physical universe. In the age of industrial entrepreneurs, waste was not a design consideration. The result was that some entrepreneurs (think Henry Ford and Thomas Edison) unwittingly contributed greatly to global warming.

Now, in the age of sustainable entrepreneurship, we must consider the biosphere as a locus for entrepreneurial activity, understand the biospheric factors that influence opportunity, eliminate waste embodied in products, and develop techniques to add value to rather than to extract value from the biosphere. We need to move beyond zero-sum input-output analysis without regard to the consequences and to apply new concepts that take into account the 'living dimension' of the products and services that we produce. This leads us to a tentative theory of biosphere entrepreneurship (see Figure 11).

Figure 11 Integrated theory of biosphere entrepreneurship (see online version for colours)

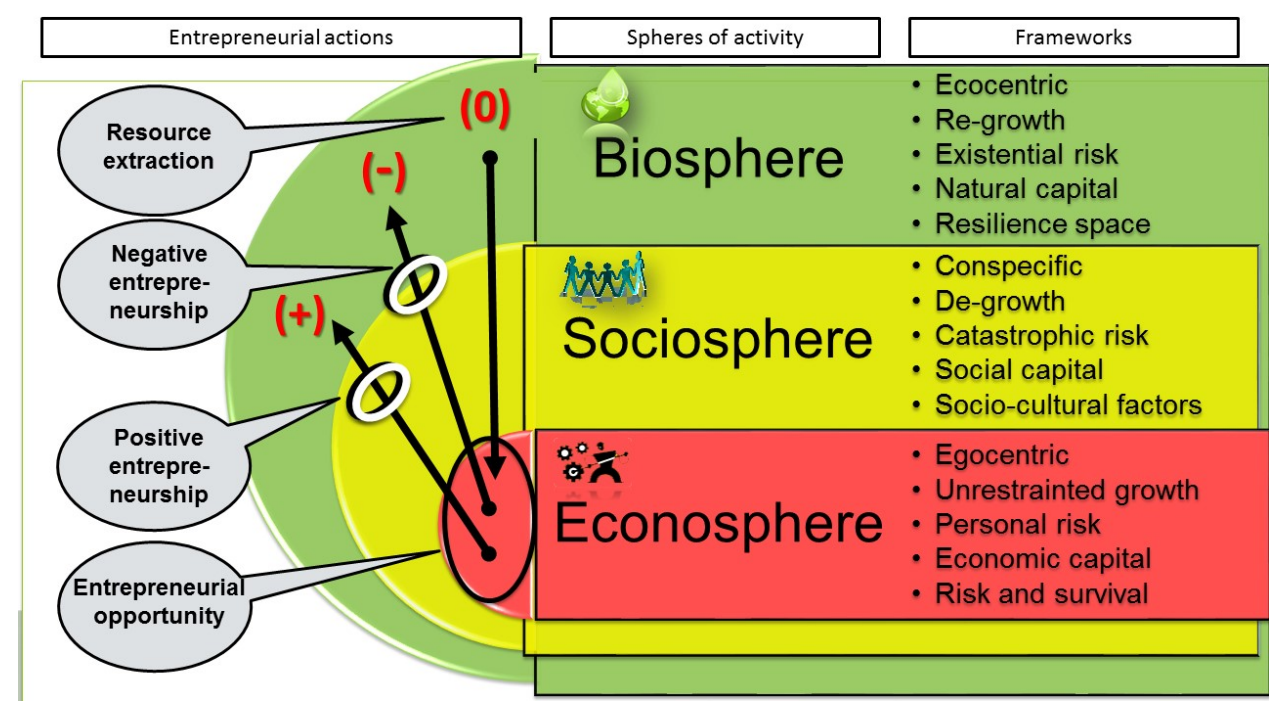


Beginning on the right, we see frameworks of observed phenomena that influence entrepreneurship action within their respective spheres of activity. Not discounting hybrids and crossovers, there are three types of (stereotypical) entrepreneurs. The business entrepreneur takes personal risks and profits personally. We call this quality egocentrism, not at all in a negative sense. These self-maximising entrepreneurs create value for themselves and their shareholders. At the next level, we have the social entrepreneur, who aims to contribute value to their conspecifics through community and social action. Finally, we have biosphere entrepreneurs who seek to increase resilience, in fact, to compensate for past and accelerating consumption, losses of biodiversity and threats to humanity.

Turning to the left-hand side of entrepreneurial actions, from a material point of view, we can see objects $(\mathrm{O})$ passing from the waste-free biosphere through the sociosphere into the realm of entrepreneurial opportunity within econosphere through the process of resource extraction and production. Next, after entrepreneurs are done with these resources, they pass them out of the econosphere as waste. Their value usually becomes negative (-), in other words, damages the environment and results in a net biosphere deficit. Throughout the history of entrepreneurship, there has been an uneven, negative exchange to the biosphere resulting in a net deficit to the planet. This is ultimately unsustainable or what we call 'negative entrepreneurship'. In contrast, the objective of 'positive entrepreneurship' is to return resources in value-adding form $(+)$ by taking advantage of entrepreneurial opportunity.

\subsection{Example of positive entrepreneurship}

Recycling usually means separating materials for disposal, but here we make the distinction between down-cycling and up-cycling. Down-cycling transforms waste materials and goods into lower uses. While it may address the post-consumer waste problem, this is a small fraction of the waste embedded in extraction and processing. The obvious example is the recycling of plastics, which turns them into lower grade plastics without regard to the huge energy losses that were incurred in their production.

With up-cycling, waste materials are advanced into new, higher-value products. This is the practice of taking something that is disposable and repurposing it into a product of higher quality. An example would be reconstructing old mattresses, repairing and reusing carpet squares, turning wooden pallets into designer furniture and converting waste into art, edible chopsticks and compostable shoes, fashion and homewares made from PET bottles and fire hoses, and camping gear that is taken back and repaired when it is worn out.

Positive entrepreneurship $(+)$ can generate positive impacts through value adding and eliminating designed waste, duplication, disposability, planned obsolescence and wasteful end purposes. Positive entrepreneurs create net-positive impact loops and levers in order restore the biosphere to pre-anthropogenic degradation and to lessen ecological footprint of human beings (Birkeland, 2007; Cohen and Winn, 2007; Dean and McMullen, 2007; Kury, 2012; Shepherd and Patzelt, 2011; Desha et al., 2016).

In sum, we have used framework analysis, a tool of ontology, to advance an integrated theory of biosphere entrepreneurship. We distinguished industrial from sustainable entrepreneurship. We now must think of the biosphere as a locus for entrepreneurial activity and take into account the 'living dimension' of what we produce. We then examined the material flows of biospheric resources into the zone of 
entrepreneurial opportunity, and observed that some of those resources are negative and are devalued. Positive entrepreneurs need to trigger impact loops that restore the biosphere and increase its resilience. Table 5 describes some components of postive and negative entrepreneurship.

Table 5 Negative and positive forms of entrepreneurship

\begin{tabular}{|c|c|}
\hline Negative entrepreneurship (-) & Positive entrepreneurship (+) \\
\hline Egocentric, individualistic, commercial & Socially connected, environmentally oriented \\
\hline Pursuit of opportunity with impunity & Responsible, ethical, sustainable consumption \\
\hline Plundering and exploitation of the biosphere & $\begin{array}{l}\text { Take advantage of climate change } \\
\text { opportunities }\end{array}$ \\
\hline Inconsistent with need to preserve the planet & Improve environment while achieving growth \\
\hline $\begin{array}{l}\text { Undervalues biodiversity and natural } \\
\text { resources }\end{array}$ & Create growth through eco-businesses \\
\hline Increases waste & Value-creating, restorative \\
\hline Subtracts value from ecosystem services & Generates value for ecosystem services \\
\hline Ignores existential risk to humanity and planet & $\begin{array}{l}\text { Takes into account catastrophic and existential } \\
\text { risks }\end{array}$ \\
\hline Contributes to the man-nature imbalance & Balances humans and nature \\
\hline Irreplaceably extracts resources & Preserves the integrity of the biotic community \\
\hline $\begin{array}{l}\text { Expels used capital with zero or negative } \\
\text { added value }\end{array}$ & Adds value to the biosphere \\
\hline $\begin{array}{l}\text { Exploits and destroy natural capital, sees } \\
\text { capital as only money }\end{array}$ & $\begin{array}{l}\text { Uses social and natural capital, conserves } \\
\text { natural capital }\end{array}$ \\
\hline Uses unsustainable performance measures & Uses measures of primordial shareholder value \\
\hline Unproductive, destructive, annihilative & Productive \\
\hline
\end{tabular}

\section{Conclusions}

What have we accomplished here? On the one hand, we have reviewed and extended extant frameworks using pictorial figures. These included entrepreneurial risk frameworks as well as frameworks that deal with finance and capital, growth, society and culture, and opportunity. We have answered the research questions in the affirmative: There is something happening here. We established that there is a third kind of entrepreneurship beyond business entrepreneurship and social entrepreneurship. We were able to sort observations into categories, extend some existing frameworks, and envision a model that ties threads together. We have been able to satisfy Kuratko et al. $(2015$, p.3) by opening up a new approach to entrepreneurship theory and by expanding the context of our field into the biosphere.

Drawing upon these concepts and structures, the author depicted a theoretical model of biosphere entrepreneurship showing how Earth, people and the entrepreneurial economy are connected. The theoretical model showed the flow of energy and materials taken from and returned to the biosphere. For the most part, throughout the history of entrepreneurship this is an uneven exchange. Unsustainable (or negative) entrepreneurs have extracted and plundered resources, thus depleting Earth's natural capital, decreasing 
its resilience, and returning these resources to the biosphere as waste in devalued form. Sustainable (or positive) entrepreneurs return these resources in value-added form.

In the end, we seek now to produce a cohort of positive entrepreneurs who can generate positive impacts through value adding and eliminating designed waste, duplication, disposability, planned obsolescence and wasteful end purposes. In so doing, positive entrepreneurs can create net positive-impact loop systems and innovations that create levers for biophysical improvements and social transformation.

\section{Implications for entrepreneurship education}

That said, I would like to comment on the implications of biosphere entrepreneurs for entrepreneurship education. Sadly, resource depletion and overpopulation are both products of the enterprising spirit. Climate change is the issue of the millennial generation. As Gen $\mathrm{Y}$ and $\mathrm{Z}$ see cities disappearing under water, as they see the hottest summers in recorded history, and as they see species disappearing, the call to save the world using entrepreneurial action has become compelling. Climate change will have a significant impact on our students' incomes and wealth during their peak earning years. Already, Generation Z, those born 1995-2009, who never knew the pre-internet world, is entering universities. They will be followed by Generation Alpha, those born after 2010, who will fare even worse (Bailey, 2016; Demos, 2016). Entrepreneurship educators must now help our young entrepreneurs deal with the existential threats facing them. Here is a review of what teachers could be imparting.

- Basics: Students need to know that economic growth and entrepreneurial activity are inextricably linked to environmental effects. Safety on Earth is slipping away. Innovation and enterprise can be a pathway to resilience and recovery. Entrepreneurs who understand the new climate reality - and are willing to invest in preparedness and risk management - are best equipped to seize opportunities.

- Climate change economics: Students need to understand the relationship of entrepreneurship to environmental economics. Market failures motivate environmentally degrading behaviour. Entrepreneurs continue to cause negative externalities, where costs to the environment spill over onto the consumer and the public, leading to the 'tragedy of the commons'. Students need to know how to hedge against physical climate risk, mitigate regulatory costs, and improve/repair corporate reputations through green business. They need to know how to manage climate risk in the supply chain, invest in low-carbon activities, and innovate new technology while improving the planet. They need to understand climate-related revenue drivers (pass-throughs to customers; carbon credits; low-carbon substitute products; impact of weather patterns on revenue), as well as cost drivers (regulatory; emissions tax; price increase in materials; energy costs; insurance premiums).

- Some entrepreneurs engage in environmental crime: The most morally questionable entrepreneurs are environmental crime enterprises. These syndicates carry out illegal fishing, illegal trade in wildlife and timber, smuggling of ozone depleting substances, illegal disposal of asbestos, shipment of animal parts for health remedies, illegal trade in charcoal, or trade in hazardous waste - all to benefit the criminal entrepreneurial syndicates. Students can relate environmental crimes that have 
occurred near them, including strip mining, damming of rivers that drive out people, atomic energy failures, industrial pollution, etc.

- Innovation in the era of climate change: Ultimately, the green revolution is going to be carried by engineers and entrepreneurs who can break down the barriers to the market and commercialise existing technologies. We need innovators to team up with entrepreneurs to produce and market breakthroughs by creating and responding to demand. Only entrepreneurs can take innovation to the marketplace. The candidates for top sustainable 21st century innovations include: genetic engineering; artificial trees; species preservation; geo-engineering; carbon sequestration; free non-fossil fuel power systems; gene sequencing; hydrogen-powered cars; methane-fuelled rockets; waste management; and weather prediction. In their venture planning, the entrepreneur should take into account methods of manufacturing and distribution that ensure a minimal environmental impact. They should consider creating products with significantly longer life spans. By creating products that are upgradable, retro-fittable, or simply indestructible, we communicate to consumers the inherent environmental and cost benefits of purchasing a product which will last a generation.

- Design thinking for the environment: What unites all great design thinkers is what famous American architect, systems theorist, designer, and inventor Buckminster Fuller called 'anticipatory design science', which he defined as human practice that would align men and women to the conscious design of our total environment, making Earth's finite resources meet the needs of humanity without disrupting the ecological processes of the planet. What nobler cause than to use design for a sustainable environment. Nobel laureate Herbert Simon agreed: 'To design is to devise courses of action aimed at changing existing situations into preferred ones' (Fuller, 1963, n.d., 1969; Simon, 1969).

- Family business in the age of environmental sustainability: Environmental sustainability is relevant to family-controlled businesses, oriented as they are towards preserving wealth and ensuring success for future generations. Climate change and global warming are affecting the fortunes and longevity of family businesses. A crop failure may mean bankruptcy. A new pollution regulation can put a family business into debt or make it uncompetitive. On the reverse side, some families take advantage of this by positioning themselves in eco-tourism. Long-term stewardship is generally a core value at family firms.

- Social intrapreneurship: Social intrapreneurs show how business and social values can be aligned. This is nowhere as true as in the field of environmental sustainability by delivering solutions or products that both add value to the company's bottom line as well as to the resilience of society and the planet. Social intrapreneurs see businesses as part of Earth's ecosystem.

- Green marketing: Marketing can decouple material consumption from consumer value and can facilitate both innovation and choice for sustainable consumption. Marketing can help consumers to find, choose and use sustainable products and services. Global consumption patterns are unsustainable. Efficiency gains and technological advances alone will not be sufficient to bring global consumption 
down to a sustainable level. Changes will also be required to consumer lifestyles, including the ways in which consumers choose and use products and services.

- Entrepreneurial strategy and sustainable development: Entrepreneurial strategy can be defined as the art of managing assets that one does not own. Earth's resources also fall into this category. New Millennial entrepreneurs need a strategy that at the same time grows the company as well as protects those resources that we do not own. New entrepreneurial strategy tools are important for young entrepreneurs to learn. The Sustainability Helix helps us understand how business can become more sustainable. Strategic backcasting is a methodology for planning under uncertain circumstances. BioDefinition guides decisions about creating or investing in a biodiversity business. BioSwot analyses strengths, weaknesses, opportunities and threats in the linkages between the business and the biodiversity. BioGovernance puts in place structures to preserve the biodiversity integrity of the business and to secure achievement of biodiversity performance. Product stewardship focuses on minimising not only pollution from manufacturing but also all environmental impacts associated with the full life cycle of a product.

- Sustainability performance measures for entrepreneurs: Companies are now talking about climate change both positively (touting their own progress on emissions reductions) and negatively (disclosing the ways in which climate change can hurt the bottom line). Entrepreneurs can now find a variety of planning, strategy and performance tools to use in launching and evaluating new sustainable ventures. Many companies are required to disclose sustainability performance measures on their progress toward sustainable development. These tools include: life cycle assessment (LCA); Factor X; ISO 14 000; environmental impact assessment (EIA); material flow analysis (MFA); TBL performance measures; carbon footprints; and food or product miles.

As entrepreneurs, we are collectively reaching the tipping point where we have to change our business models to respond to sustainability issues. We can and must advance sustainable development initiatives, taking into account the importance of mitigating and adapting to climate change. We now need to plan for every final impact of their business with sections on greenhouse gases, energy use, clean power and other emissions-reducing strategies.

\section{Acknowledgements}

The author wishes to thank the Eugenio Garza Lagüera Entrepreneurship Institute, Monterrey Institute of Technology, Puebla, Mexico; and Plymouth State University's (New Hampshire) Innovation \& Entrepreneurship Cluster for supporting me during the writing; and the United States Association for Small Business and Entrepreneurship (USASBE) for recognising this paper with an award. 


\section{References}

Aggestam, M. (2014) 'Conceptualizing entrepreneurial capital in the context of institutional change', International Entrepreneurship and Management Journal, Vol. 10, No. 1, pp.165-186 [online] https://link.springer.com/article/10.1007/s11365-011-0216-x (accessed 8 December 2017).

Alexander, R.D. (1987) The Biology of Moral Systems, A. de Gruyter, Hawthorne, N.Y.

Alexius, S. and Furusten, S. (2013) 'Dilemmas of hybrid social enterprises: the case of the natural step Sweden', in 29th EGOS Colloquium, Subtheme 33 Management Occupations: Exploring Boundaries and Knowledge Flows, Montreal 4-6 July [online] http://www.diva-portal.org/smash/record.jsf?pid=diva2:678514 (accessed 8 December 2017).

Alvarez, C. and Urbano, D. (2012) 'Environmental factors and entrepreneurial activity: an institutional approach (Factores Del Entorno Y Creación de Empresas: Un Análisis Institucional)', Revista Venezolana de Gerencia, Vol. 17, No. 57, pp.9-38 [online] https://papers.ssrn.com/sol3/papers.cfm?abstract_id=2043480 (accessed 8 December 2017).

Anderson, A.R. (1998) 'Cultivating the garden of eden: environmental entrepreneuring', Journal of Organizational Change Management, Vol. 11, No. 2, p.135 [online] http://www.emeraldinsight.com/doi/abs/10.1108/09534819810212124 (accessed 8 December 2017).

Anderson, A.R. and Smith, R. (2007) 'The moral space in entrepreneurship: an exploration of ethical imperatives and the moral legitimacy of being enterprising, Entrepreneurship and Regional Development, Vol. 19, No. 6, pp.479-497 [online] http://www.tandfonline.com/doi/abs/10.1080/08985620701672377 (accessed 8 December 2017).

Anderson, T.L. and Leal, D. (1997) Enviro-Capitalists: Doing Good While Doing Well, The Political Economy Forum, Lanham, Md., Rowman \& Littlefield Publishers.

Andersson, J.O. and Eriksson, R. Eds. (2010) 'Growth and degrowth: is another economy possible?', in Elements of Ecological Economics, pp.125-136, Routledge [online] https://goo.gl/KPij4C (accessed 8 December 2017).

Assadourian, E. (2012) 'The path to degrowth in overdeveloped countries', in Starke, pp.978-1, State of the World 2012: Moving toward sustainable prosperity, Island Press/Center for Resource Economics, ISBN:-61091-037-8 [online] https://link.springer.com/chapter/10.5822/978-1-61091-045-3_2 (accessed 8 December 2017).

Austin, J., Stevenson, H. and Wei-Skillern, J. (2006) 'Social and commercial entrepreneurship: same, different, or both?', Entrepreneurship Theory and Practice, Vol. 30, No. 1, pp.1-22 [online] http://www.onlinelibrary.wiley.com/doi/10.1111/j.1540-6520.2006.00107.x/abstract (accessed 8 December 2017).

Azmat, F. (2013) 'Sustainable development in developing countries: the role of social entrepreneurs', International Journal of Public Administration, Vol. 36, No. 5, pp.293-304 [online] http://www.tandfonline.com/doi/abs/10.1080/01900692.2012.756891.

Baggs, J. (2005) 'Firm survival and exit in response to trade liberalization', Canadian Journal of Economics/Revue Canadienne D'économique, Vol. 38, No. 4, pp.1364-1383 [online] http://www.onlinelibrary.wiley.com/doi/10.1111/j.0008-4085.2005.00328.x/full (accessed 8 December 2017).

Bailey, R. (2016) 'Climate change will impoverish millennials,says study - hit \& run', Reason.com [online] http://www.reason.com/blog/2016/08/24/climate-change-will-impoverish-millennia (accessed 8 December 2017).

Balazs, Z. (2013) 'The instantiation of values', SpringerPlus, Vol. 2, No. 1, p.166, DOI: $10.1186 / 2193-1801-2-166$.

Bandura, A. (1986) Social Foundations of Thought and Action: A Social Cognitive Theory, Prentice-Hall, Inc. [online] http://psycnet.apa.org/record/1985-98423-000 (accessed 12 December 2017). 
Bandura, A. (2001) 'Social cognitive theory: an agentic perspective', Annual Review of Psychology, Vol. 52, No. 1, pp.1-26 [online] http://www.annualreviews.org/doi/abs/10.1146/annurev.psych.52.1.1 (accessed 8 December 2017).

Bandura, A., Barbaranelli, C., Caprara, G.V. and Pastorelli, C. (1996) 'Mechanisms of moral disengagement in the exercise of moral agency', Journal of Personality and Social Psychology, Vol. 71, No. 2, p.364 [online] http://psycnet.apa.org/record/1996-06400-013 (accessed 8 December 2017).

Baumol, W.J. (1990) 'Entrepreneurship: productive, unproductive, and destructive', Journal of Political Economy, Vol. 98, No. 5, pp.893-921 [online] http://www.journals.uchicago.edu/doi/abs/10.1086/261712 (accessed 8 December 2017).

BBC (2009) 'Geo-engineering', November 17, sec. Technology [online] http://news.bbc.co.uk/2/hi/technology/8338853.stm (accessed 8 December 2017).

Begley, T.M. and Tan, W-L. (2001) 'The socio-cultural environment for entrepreneurship: a comparison between east Asian and Anglo-Saxon countries', Journal of International Business Studies, (Quarter), No. 3, p.537 [online] http://link.springer.com/article/10.1057/palgrave.jibs.8490983 (accessed 8 December 2017).

Bennett, S.J. (1991) Ecopreneuring: The Complete Guide to Small Business Opportunities from the Environmental Revolution, Wiley, New York.

Bergstrand, B-O., Björk, F. and Molnar, S. (2011) 'Biosphere-entrepreneurship-a-pilot-studySkaraborg', Sweden: Biosphere Reserve Lake Vänern Archipelag [online] http://media.vanerkulle.org/2013/09/297 Biosphere-Entrepreneurship-A-Pilot-StudyWebversion.pdf (accessed 8 December 2017).

Berle, G. (1991) The Green Entrepreneur: Business Opportunities that Can Save the Earth, Liberty Hall Press, Blue Ridge Summit.

Bethune, B. (2016) 'Is geoengineering the solution to saving the earth?', Macleans, January 12 [online] http://www.macleans.ca/society/science/is-geoengineering-the-solution-to-saving-theearth/ (accessed 8 December 2017).

Birkeland, J. (2007) 'Positive development: designing for net positive impacts', Environment Design Guide, pp.1-8 [online] http://www.jstor.org/stable/26148727 (accessed 9 December 2017).

Björk, F. (2011) Part 1: What is biosphere entrepreneurship? Biosfär Vänerskärgården Kinnekulle [online] http://muep.mau.se/handle/2043/16769 (accessed 8 December 2017).

Björk, F. and Olsson, P. (2013) 'Understanding supportive networks for social-ecological innovation', Presented at Nordic Environmental Social Science Conference, Copenhagen [online] https://muep.mau.se/handle/2043/16361 (accessed 9 December 2017).

Black, B.C. (2014) 'Hubbert M. King', in Li, X. and Molina, M. (Eds.): Oil: A Cultural and Geographic Encyclopedia of Black Gold, 14 October, 2 volumes, Vol. 2, pp.128-129, ABC-CLIO [online] https://goo.gl/eQjdba (accessed 8 December 2017).

Blue, J. (1991) Ecopreneuring: Managing for Results, Scott Foresman, London.

Blundell, R., Griffith, R. and Van Reenen, J. (1995) 'Dynamic count data models of technological innovation', Economic Journal, Vol. 105, No. 429, pp.333-344 [online] http://www.jstor.org/2235494 (accessed 8 December 2017).

Boons, F. and Wagner, M. (2009) 'Assessing the relationship between economic and ecological performance: distinguishing system levels and the role of innovation', Ecological Economics, Vol. 68, No. 7, pp.1908-1914 [online] http://www.sciencedirect.com/science/article/pii/S0921800909000743 (accessed 8 December 2017).

Bostan, I., Gheorghe, A.V., Dulgheru, V., Sobor, I., Bostan, V. and Sochirean, A. (2012) Resilient Energy Systems: Renewables: Wind, Solar, Hydro., Vol. 19, Springer Science \& Business Media [online] https://goo.gl/peyRpP (accessed 8 December 2017). 
Bostrom, N. (2013) 'Existential risk prevention as global priority', Global Policy, Vol. 4, No. 1, pp.15-31 [online] http://www.onlinelibrary.wiley.com/doi/10.1111/1758-5899.12002/full (accessed 8 December 2017).

Bostrom, N. and Cirkovic. M.M. (2011) Global Catastrophic Risks, 1st ed., Oxford University Press, Oxford [online] https://goo.gl/dxJJSe (accessed 8 December 2017).

Boulding, K. E. (1996) 'The economics of the coming spaceship earth', in Daley, H.E and Townsend, K.N. (Eds.): Valuing the Earth: Economics, Ecology, Ethics, pp.297-310, MIT Press [online] https://goo.gl/dW8UW1 (accessed 8 December 2017).

Boulding, K.E. (1970) Economics as a Science, McGraw-Hill, New York.

Bradbury, H. and Clair, J.A. (1999) 'Promoting sustainable organizations with sweden's natural step', Academy of Management Executive, Vol. 13, No. 4, pp.63-74.

Braungart, M. and McDonough, W. (2002) Cradle to Cradle: Remaking the Way We Make Things, 1st ed., North Point Press, New York.

Breslin, D. (2008) 'A review of the evolutionary approach to the study of entrepreneurship', International Journal of Management Reviews, Vol. 10, No. 4, pp.399-423 [online] http://www.onlinelibrary.wiley.com/doi/10.1111/j.1468-2370.2008.00234.x/full (accessed 8 December 2017).

Brophy, D.J. and Shulman, J.M. (1992) 'A finance perspective on entrepreneurship research', Entrepreneurship Theory and Practice, Vol. 16, No. 3, pp.61-71 [online] http://www.goo.gl/mdcLMv (accessed 8 December 2017).

Brundtland, G.H. (1987) World Commission on Environment and Development: Our Common Future, Oxford University Press, Oxford [online] http://www.un-documents.net/wced-ocf.htm (accessed 8 December 2017).

Buch-Hansen, H. (2014) 'Capitalist diversity and de-growth trajectories to steady-state economies', Ecological Economics, Vol. 106, pp.167-173 [online] http://www.sciencedirect.com/science/journal/09218009/106 (accessed 8 December 2017).

Burns, T.R. and Witoszek, N. (2012) 'Brundtland report revisited: toward a new humanist agenda', Journal of Human Ecology, Vol. 39, No. 2, pp.155-170 [online] https://goo.gl/mqM2YL (accessed 8 December 2017).

Campbell, K. (2008) 'Women, mother earth and the business of living', in Steyaert, C. and Hjorth, D. (Eds.): Entrepreneurship as Social Change: A Third New Movements in Entrepreneurship Book, Vol. 3, p.165+, Edward Elgar Publishing, Northampton, MA [online] https://goo.gl/bW3ME5 (accessed 9 December 2017).

Cantillon, R. Ed. (2001) 'Essays on the nature of commerce in general', Classics in Economics Series: Classics in Economics, Transaction Publishers, New Brunswick, N.J.

Carland, J.W., Hoy, F., Boulton, W.R. and Carland, J.A.C. (1984) 'Differentiating entrepreneurs from small business owners: a conceptualization', Academy of Management Review, Vol. 9, No. 2, pp.354-359 [online] http://amr.aom.org/content/9/2/354.short (accessed 8 December 2017).

Carson, R., Darling, L. and Darling, L. (1962) Silent Spring, Houghton Mifflin, Riverside Press, Boston Cambridge, Mass.

Cohen, B. and Winn, M.I. (2007) 'Market imperfections, opportunity and sustainable entrepreneurship', Journal of Business Venturing, Vol. 22, No. 1, pp.29-49, DOI: 10.1016/j.jbusvent.2004.12.001.

Cohen, B., Smith, B. and Mitchell, R. (2008) 'Toward a sustainable conceptualization of dependent variables in entrepreneurship research', Business Strategy and the Environment, Vol. 17, No. 2, pp.107-119 [online] http://www.onlinelibrary.wiley.com/doi/10.1002/bse.505/full (accessed 8 December 2017).

Cole, A.H. (1959) Business Enterprise in Its Social Setting, Harvard University Press, Cambridge [online] https://goo.g1/R3MNoQ (accessed 9 December 2017). 
Cotton-Barratt, O., Farquhar, S., Halstead, J., Schubert, S. and Snyder-Beattie, A. (2015) 'Global catastrophic risks 2016', Oxford: Global Challenges Foundation [online] http://www.globalchallenges.org/reports/Global-Catastrophic-Risk-Annual-Report-2016.pdf (accessed 8 December 2017).

Crate, S.A. and Nuttall, M. (2016) Anthropology and Climate Change: From Encounters to Actions, Routledge, New York [online] https://goo.gl/as1L8y (accessed 8 December 2017).

Dagnino, G.B. and Mariani, M.M. (2007) 'Dynamic gap bridging and realized gap set development: the strategic role of the firm in the coevolution of capability space and opportunity space', in Cantner, U. and Malerba, F. (Eds.): Innovation Industrial Dynamics and Structural Transformation: Schumpeterian Legacies, pp.321-341, Springer, Berlin \& New York.

Davidsson, P. (1989) 'Entrepreneurship - and after? A study of growth willingness in small firms', Journal of Business Venturing, Vol. 4, No. 3, pp.211-226 [online] http://www.sciencedirect.com/science/article/pii/0883902689900220 (accessed 8 December 2017).

Davidsson, P., Delmar, F. and Wiklund, J. (2006) Entrepreneurship and the Growth of Firms, Edward Elgar Publishing, North Hampton, MA [online] https://goo.gl/C48X19 (accessed 8 December 2017).

De Landa, M. (1997) Thousand Years of Nonlinear History, Zone Books New York [online] http://www.library.wur.nl/WebQuery/clc/1919300 (accessed 8 December 2017).

Dean, T.J. and McMullen, J.S. (2007) 'Toward a theory of sustainable entrepreneurship: reducing environmental degradation through entrepreneurial action', Journal of Business Venturing, Vol. 22, No. 1, pp.50-76, DOI: 10.1016/j.jbusvent.2005.09.003 [online] http://www.sciencedirect.com/science/article/pii/S0883902605000777 (accessed 8 December 2017).

Dees, J.G. (1998) 'The meaning of 'social entrepreneurship', Comments and Suggestions Contributed from the Social Entrepreneurship Founders Working Group, Durham, NC: Center for the Advancement of Social Entrepreneurship, Fuqua School of Business, Duke University.

Demos. (2016) The Price Tag of Being Young: Climate Change and Millennials' Economic Future', Demos [online] http://www.demos.org/publication/price-tag-being-young-climatechange-and-millennials-economic-future (accessed 8 December 2017)

Desai, S. and Acs, Z.J. (2007) A Theory of Destructive Entrepreneurship [online] https://papers.ssrn.com/sol3/papers.cfm?abstract_id=1029648 (accessed 8 December 2017).

Desha, P.W.N., Beatley, C.T. and Birkeland, J.L. (2016) 'Net positive biophilic urbanism', Smart and Sustainable Built Environment, Vol. 5, No. 1, pp.9-14 [online] http://www.emeraldinsight.com/doi/abs/10.1108/SASBE-10-2015-0034 (accessed 8 December 2017).

Diesendorf, M. and Hamilton, C. (1997) Human Ecology, Human Economy: Ideas for an Ecologically Sustainable Future, St. Leonards, NSW, Allen \& Unwin, Australia.

Dietz, T., Fitzgerald, A. and Shwom, R. (2005) 'Environmental values', Annual Review of Environment and Resources, Vol. 30, pp.335-372.

Dimov, D. (2011) 'Grappling with the unbearable elusiveness of entrepreneurial opportunities', Entrepreneurship Theory and Practice, Vol. 35, No. 1, pp.57-81 [online] http://www.onlinelibrary.wiley.com/doi/10.1111/j.1540-6520.2010.00423.x/full (accessed 8 December 2017).

Driscoll, C. and Starik, M. (2004) 'The primordial stakeholder: advancing the conceptual consideration of stakeholder status for the natural environment', Journal of Business Ethics, Vol. 49, No. 1, pp.55-73 [online] https://link.springer.com/article/10.1023/B:BUSI.0000013852.62017.0e (accessed 8 December 2017).

Dubini, P. (1987) Motivational and Environmental Influences on Business Start-Ups: Some Hints for Public Policy, Wharton School of the University of Pennsylvania, Snider Entrepreneurial Center. 
Ebben, J. (2005) Managing Risk in a New Venture [online] https://www.inc.com/resources/ startup/articles/20050301/risk.html (accessed 8 December 2017).

Edelman, L. and Yli-Renko, H. (2010) 'The impact of environment and entrepreneurial perceptions on venture-creation efforts: bridging the discovery and creation views of entrepreneurship', Entrepreneurship Theory and Practice, Vol. 34, No. 5, pp.833-856 [online] http://www.onlinelibrary.wiley.com/doi/10.1111/j.1540-6520.2010.00395.x/full (accessed 8 December 2017).

Ehrlich, P.R. (1968) The Population Bomb: Population Control or Race to Oblivion?, Ballantine Books, New York [online] https://goo.gl/1GnevJ (accessed 8 December 2017).

Elkington, J. (1994) 'Towards the sustainable corporation: win-win-win business strategies for sustainable development', California Management Review, Vol. 36, No. 2, pp.90-100.

Elkington, J. (1997) Cannibals with Forks: The Triple Bottom Line of 21st Century Business, Capstone Publishing, Oxford.

Elkington, J. and Burke, T. (1989) The Green Capitalists, Victor Gollancz, London.

Erikson, T. (2002) 'Entrepreneurial capital: the emerging venture's most important asset and competitive advantage', Journal of Business Venturing, Vol. 17, No. 3, pp.275-290 [online] http://www.sciencedirect.com/science/article/pii/S0883902600000628 (accessed 8 December 2017).

Esteve-Pérez, S. and Mañez-Castillejo, J.A. (2008) 'The resource-based theory of the firm and firm survival', Small Business Economics, Vol. 30, No. 3, pp.231-249 [online] https://link.springer.com/article/10.1007/s11187-006-9011-4 (accessed 8 December 2017).

Field, C.B., Barros, V.R., Mastrandrea, M.D., Mach, K.J., Abdrabo, M.A-K., Adger, N., Yohe, G.W. (2014). Summary for Policymakers [Inbook] [online] http://epic.awi.de/37531/1/WG2AR5_SPM_FINAL-2.pdf (accessed 8 December 2017).

Fletcher, D.E. (2006) 'Entrepreneurial processes and the social construction of opportunity', Entrepreneurship and Regional Development, Vol. 18, No. 5, pp.421-440 [online] $\mathrm{http} / / /$ www.tandfonline.com/doi/abs/10.1080/08985620600861105 (accessed 8 December 2017).

Forum for the Future (n.d) 'The five capitals model - a framework for sustainability', Forum for the Future [online] https://www.forumforthefuture.org/sites/default/files/project/downloads/ five-capitals-model.pdf (accessed 8 December 2017).

Fountain, H. (2012) A Rogue Climate Experiment Outrages Scientists, New York Times, [online] http://www.nytimes.com/2012/10/19/science/earth/iron-dumping-experiment-inpacific-alarms-marine-experts.html?emc=eta1\&_r=3\& (accessed 8 December 2017).

Franchetti, M. and Apul, D. (2012) Carbon Footprint Analysis: Concepts, Methods, Implementation, and Case Studies, 1st ed., CRC Press, Boca Raton, FL [online] https://goo.gl/C7iVD9 (accessed 8 December 2017).

Frederick, H.H. (2017) 'Understanding biosphere entrepreneurship through a framework approach: including implications for entrepreneurship education (USASBE)', in United States Association for Small Business and Entrepreneurship, Conference Proceedings, 106, United States Association for Small Business and Entrepreneurship [online] https://icsb.org/wpcontent/uploads/2017/02/HHFrederick_UnderstandingBiosphereEntrepreneurshipthroughaFra meworkApproach.pdf (accessed 8 December 2017).

Frederick, H.H., O'Connor, A. and Kuratko, D.F. (2016) Entrepreneurship Theory Process Practice, 4th Asia-Pacific ed., Cengage Learning Australia, Melbourne, Australia.

Fry, J. (2013) 'Improving integration of agriculture and conservation through biosphere reserves', RIRDC, Publication No. 13/022 RIRDC Project No. PRJ-006634, Australian Government, Rural Industries Research and Development Corporation [online] http://www.agrifutures.com.au/wp-content/uploads/publications/13-022.pdf (accessed 8 December 2017).

Fuller, R.B. (1963) A Comprehensive Anticipatory Design Science. In No More Secondhand God: And Other Writings, Southern Illinois University Press, pp.75-104. 
Fuller, R.B. (1969) Operating Manual for Spaceship Earth, Southern Illinois University Press, Carbondale [online] http://designsciencelab.com/resources/OperatingManual_BF.pdf.

Fuller, R.B. (n.d.) Eight Strategies for Comprehensive Anticipatory Design Science, The Buckminster Fuller Institute [online] https://www.bfi.org/design-science/primer/eightstrategies-comprehensive-anticipatory-design-science.

Gardner, G.T. and Stern, P.C. (1996) Environmental Problems and Human Behavior, Allyn \& Bacon [online] http://psycnet.apa.org/record/1996-97587-000 (accessed 8 December 2017).

Gartner, W.B. (1990) 'What are we talking about when we talk about entrepreneurship?', Journal of Business Venturing, Vol. 5, No. 1, pp.15-28 [online] http://www.sciencedirect.com/science/article/pii/088390269090023M (accessed 8 December 2017).

George, C., and Reed, M. (2015) 'Building institutional capacity for environmental governance through social entrepreneurship: lessons from Canadian biosphere reserves', Ecology and Society, Vol. 21, No. 1, DOI: 10.5751/ES-08229-210118.

Gielnik, M.M., Zacher, H. and Frese, M. (2012) 'Focus on opportunities as a mediator of the relationship between business owners' age and venture growth', Journal of Business Venturing, Vol. 27, No. 1, pp.127-142 [online] http://www.sciencedirect.com/science/article/pii/S0883902610000558 (accessed 8 December 2017).

Gowdy, J. (2013) Coevolutionary Economics: The Economy, Society and the Environment, Vol. 5, Springer Science \& Business Media, Berlin [online] https://goo.gl/uqjZuM (accessed 8 December 2017).

Gray, B.J., Duncan, S., Kirkwood, J. and Walton, S. (2014) 'Encouraging sustainable entrepreneurship in climate-threatened communities: a Samoan case study', Entrepreneurship \& Regional Development, Vol. 26, pp.401-430 [online] http://link.springer.com/chapter/10.1007/978-3-319-20146-7_3 (accessed 8 December 2017).

Gray, N.F. (2015) 'The concept of resources', in Facing Up to Global Warming, pp.53-77, Springer [online] http://www.link.springer.com/chapter/10.1007/978-3-319-20146-7_3.

Grisham, T. (2009) 'Leading sustainability', World Review of Entrepreneurship, Management and Sustainable Development, Vol. 5, No. 1, pp.42-55.

Hayton, J.C., George, G. and Zahra, S.A. (2002) 'National culture and entrepreneurship: a review of behavioral research', Entrepreneurship Theory and Practice, Vol. 26, No. 4, p.33 [online] http://www.ink.library.smu.edu.sg/lkcsb_research/4642/ (accessed 8 December 2017).

Hébert, R.F. and Link, R. (2009) A History of Entrepreneurship, Routledge, North Hampton, MA [online] https://goo.gl/uTLyie (accessed 8 December 2017).

Herbertson, J. and Tipler, C. (2006) 'The natural step framework: From sustainability fundamentals to innovation', in Marinova, D. (Ed.): International Handbook on Environmental Technology Management [online] https://goo.gl/CjpGhr (accessed 8 December 2017).

Hofstede, G.H. (1984) Culture's Consequences: International Differences in Work-Related Values, Abridged ed., Sage Publications, Beverly Hills.

Hofstra, N. (2015) 'Entrepreneurship Inspired by nature', in The Spiritual Dimension of Business Ethics and Sustainability Management, pp.159-166, Springer, Berlin [online] https://link.springer.com/chapter/10.1007/978-3-319-11677-8_13 (accessed 8 December 2017).

Hofwebwer, T. (2004) 'Logic and ontology', in Stanford Encyclopedia of Philosophy [online] https://plato.stanford.edu/entries/logic-ontology/ (accessed 8 December 2017).

Holmberg, J. (2006) 'Backcasting the natural step: a vision for sustainable societies', Reflections, Vol. 7, No. 3, pp.9-14.

Holmberg, J., Robert, K-H. and Eriksson, K-E. (1996) 'Socio-ecological principles for a sustainable society: scientific background and swedish experience', in Olman, S., Costanza, R. and Martinez-Alier, J. (Eds.): Getting down to Earth: Practical Applications of Ecological Economics, pp.17-48, Island Press/International Society of Ecological Economics, Washington. 
Holmgren, D. (2012) Future Scenarios: How Communities Can Adapt to Peak Oil and Climate Change, Chelsea Green Publishing, Hartford, VT [online] https://goo.gl/cDCgr4 (accessed 8 December 2017).

Hubbert, M.K. (1982) Techniques of Prediction as Applied to the Production of Oil and Gas, National Bureau of Standards, Washington [online] https://goo.gl/A9EDZZ (accessed 8 December 2017).

Jack, S.L. and Anderson, A.R. (1998) 'Entrepreneurship education within the condition of entreprenology', in Proceedings of the Conference on Enterprise and Learning, pp.13-28.

Janney, J.J. and Dess, G.G. (2006) 'The risk concept for entrepreneurs reconsidered: new challenges to the conventional wisdom', Journal of Business Venturing, Vol. 21, No. 3, pp.385-400 [online] http://www.sciencedirect.com/science/article/pii/S0883902605000558 (accessed 8 December 2017).

Jolink, A. and Niesten, E. (2015) 'Sustainable development and business models of entrepreneurs in the organic food industry', Business Strategy and the Environment, Vol. 24, No. 6, pp.386-401, DOI: 10.1002/bse.1826.

Kallis, G. (2011) 'In defence of degrowth', Ecological Economics, Vol. 70, No. 5, pp.873-880 [online] http://www.sciencedirect.com/science/article/pii/S0921800910005021 (accessed 8 December 2017).

Kets de Vries, M.FR. (1985) The Dark Side of Entrepreneurship, SSRN Scholarly Paper No. ID 1505242, Social Science Research Network, Rochester, NY [online] https://papers.ssrn.com/abstract=1505242 (accessed 8 December 2017).

Kirkwood, J. and Walton, S. (2014) 'How green is green? Ecopreneurs balancing environmental concerns and business goals', Australasian Journal of Environmental Management, Vol. 21, No. 1, pp.37-51 [online] http://www.tandfonline.com/doi/abs/10.1080/ 14486563.2014.880384 (accessed 8 December 2017).

Kirzner, I.M. Ed. (1985) Discovery and the Capitalist Process, University of Chicago Press, Chicago.

Klare, M. (2012) The Race for What's Left: The Global Scramble for the World's Last Resources, Reprint edition, Picador, New York.

Klare, M.T. (2017) 'Climate change as genocide: inaction equals annihilation', Huffington Post [online] http://www.huffingtonpost.com/entry/climate-change-as-genocide-inaction-equalsannihilation_us 58f8c4a3e4b0cb086d7eaf4e (accessed 8 December 2017).

Klitgaard, KA. and Krall, L. (2012) 'Ecological economics, degrowth, and institutional change', Ecological Economics, Vol. 84, pp.247-253 [online] http://www.sciencedirect.com/science/article/pii/S0921800911004897 (accessed 8 December 2017).

Koe, W-L., Sa'ari, J.R., Majid, I.A. and Ismail, K. (2012) 'Determinants of entrepreneurial intention among millennial generation', Procedia-Social and Behavioral Sciences, Vol. 40, pp.97-208 [online] http://www.sciencedirect.com/science/article/pii/S1877042812006489 (accessed 8 December 2017).

Kondratieff, N.D. (1922) World Economy and Its Conjuncture during and after the War, Vologda: Regional Branch of the State Publishing House, Russian.

Kuratko, D.F., Morris, M.H. and Schindehutte, M. (2015) 'Understanding the dynamics of entrepreneurship through framework approaches', Small Business Economics, Vol. 45, No. 1, pp.1-13 [online] http://www.link.springer.com/article/10.1007/s11187-015-9627-3 (accessed 8 December 2017).

Kury, K.W. (2012) 'Sustainability meets social entrepreneurship: a path to social change through institutional entrepreneurship', International Journal of Business Insights \& Transformation, Vol. 4, No. 3, pp.64-71 [online] http://www.ijbit.org/pdfs/archives.pdf (accessed 9 December 2017). 
Leopold, A. (1970) A Sand County Almanac, 1949, Oxford University Press, New York [online] https://www.aldoleopold.org/about/aldo-leopold/sand-county-almanac/ (accessed 8 December 2017).

Lewis, V.L. and Churchill, N.C. (1983) 'The five stages of small business growth', Harvard Business Review, Vol. 61, No. 3, pp.30-50 [online]

http://www.papers.ssrn.com/sol3/papers.cfm?abstract_id=1504517 (accessed 8 December 2017).

List of Proposed Geoengineering Schemes (2016) Wikipedia, The Free Encyclopedia [online] https://goo.gl/JXNK9G (accessed 8 December 2017).

Lockwood, F., Teasley, R., Carland, J.A.C. and Carland, J.W. (2006) 'An examination of the power of the dark side of entrepreneurship', International Journal of Family Business, Vol. 3, pp.120 [online]

https://sites.google.com/a/uca.edu/sbanc/international-journal-of-family-business (accessed 8 December 2017).

Lowitt, E. (2014) 'How to survive climate change and still run a thriving business', Harvard Business Review, Vol. 92, No. 4, pp.86-92 [online] $\mathrm{http}: / /$ europepmc.org/abstract/med/24830284 (accessed 8 December 2017).

Lukacs, M. (2012) 'World's biggest geoengineering experiment 'violates' UN rules', The Guardian, October 15 [online] http://www.theguardian.com/environment/2012/oct/15/pacificiron-fertilisation-geoengineering (accessed 8 December 2017).

MacNeill, J. (2013) 'Brundtland revisited', Canadian International Council, February, Vol. 4 [online] https://www.opencanada.org/features/brundtland-revisited/ (accessed 8 December 2017).

Majid, I.A. and Koe, W-L. (2012) 'Sustainable entrepreneurship (SE): a revised model based on triple bottom line (TBL)', International Journal of Academic Research in Business and Social Sciences, Vol. 2, No. 6, p.293 [online] http://eprints.utem.edu.my/11492/ (accessed 8 December 2017).

Majid, S. and Yaqun, Y. (2016) 'From an entrepreneur to a sustainopreneur: extracting facts about sustainopreneurship', The East Asian Journal of Business Management, Vol. 6, No. 2, pp.23-25 [online] http://www.db.koreascholar.com/article?code=314013 (accessed 8 December 2017).

Malthus, T.R. (1878) An Essay on the Principle of Population: Or, a View of Its Past and Present Effects on Human Happiness, with an Inquiry Into our Prospects Respecting the Future Removal or Mitigation of the Evils Which It Occasions, Reeves and Turner, London.

Markman, G.D., Russo, M., Lumpkin, G.T., Jennings, P. and Mair, J. (2016) 'Entrepreneurship as a platform for pursuing multiple goals: a special issue on sustainability, ethics, and entrepreneurship', Journal of Management Studies, Vol. 53, No. 5, pp.673-694.

Martin, D.M. and Schouten, J.W. (2014) 'Sustainable marketing through the natural step', in Humanistic Marketing, pp.231-243, Palgrave Macmillan, London [online] https://link.springer.com/chapter/10.1057/9781137353290_18 (accessed 8 December 2017).

Mason, C. and Harrison, R. (2004) 'Does investing in technology-based firms involve higher risk? An exploratory study of the performance of technology and non-technology investments by business angels', Venture Capital: An International Journal of Entrepreneurial Finance, Vol. 6, No. 4, pp.313-332 [online] http://www.tandfonline.com/doi/abs/10.1080/1369106042000286471 (accessed 8 December 2008).

Meadows, D.H., Meadows, D.L., Randers, J. and Behrens, W.W. (1972) The Limits to Growth: A Report for the Club of Rome's Project on the Predicament of Mankind, New American Library.

Morris, M.H., Kuratko, D.F. and Schindehutte, M. (2001a) 'Towards integration: understanding entrepreneurship through frameworks', The International Journal of Entrepreneurship and Innovation, Vol. 2, No. 1, pp.35-49. 
Morris, M.H., Kuratko, D.F. and Schindehutte, M. (2001b) 'Understanding entrepreneurship through frameworks', The International Journal of Entrepreneurship and Innovation, Vol. 2, pp.35-49.

Morton, O. (2015) The Planet Remade: How Geoengineering Could Change the World, Princeton University Press, Princeton, N.J.

Mulder, P. and Van Den Bergh, J.C.J.M. (2001) 'Evolutionary economic theories of sustainable development', Growth and Change, Vol. 32, No. 1, pp.110-134 [online] http://onlinelibrary.wiley.com/doi/10.1111/0017-4815.00152/full (accessed 8 December 2017).

Murphy, K.M., Shleifer, A. and Vishny, R.W. (1991) 'The allocation of talent: implications for growth', The Quarterly Journal of Economics, Vol. 106, No. 2, pp.503-530 [online] https://academic.oup.com/qje/article-abstract/106/2/503/1905462 (accessed 8 December 2017).

Nagler, J. (2012) 'Entrepreneurs: the world needs you', Thunderbird International Business Review, Vol. 54, No. 1, pp.3-5 DOI: 10.1002/tie.21433.

Nattrass, B. and Altomare, M. (2013) The Natural Step for Business: Wealth, Ecology \& the Evolutionary Corporation, New Society Publishers, Vancouver [online] https://www.newsociety.com/Books/N/The-Natural-Step-for-Business (accessed 8 December 2017).

Nattrass, B. and Altomare. M. (1999) 'IKEA: nothing is impossible', Journal of Business Administration \& Policy Analysis, Vol. 27, No. 9, pp.429-458.

Nguyen, C., Frederick, H. and Nguyen, H. (2014) 'Female entrepreneurship in rural Vietnam: an exploratory study', International Journal of Gender and Entrepreneurship, Vol. 6, No. 1, pp.50-67 [online] http://www.emeraldinsight.com/doi/abs/10.1108/IJGE-04-2013-0034 (accessed 8 December 2017).

Nordlund, A.M. and Garvill, J. (2003) 'Effects of values, problem awareness, and personal norm on willingness to reduce personal car use', Journal of Environmental Psychology, Vol. 23, No. 4, pp.339-347 [online] http://www.sciencedirect.com/science/article/pii/S0272494403000379 (accessed 8 December 2017).

Norton, M. (2012) Sustainability: Duty or Opportunity For Business?, Routledge, North Hampton, MA [online] https://www.routledge.com/Sustainability-Duty-or-Opportunity-forBusiness/Norton/p/book/9780415529334 (accessed 8 December 2017).

OECD (2008) Defining Entrepreneurial Activity: Definitions Supporting Frameworks for Data Collection [online] http://www.papers.ssrn.com/sol3/papers.cfm?abstract_id=1090372 (accessed 8 December 2008).

Orihuela, J.C. (2017) 'Assembling participatory Tambopata: environmentality entrepreneurs and the political economy of nature', Forest Policy and Economics, Vol. 80, pp.52-62 [online] http://www.sciencedirect.com/science/article/pii/S1389934117301569 (accessed 8 December 2017).

Parrish, B.D. (2007) Sustainability Entrepreneurship: Design Principles, Processes, and Paradigms, University of Leeds [online] http://www.etheses.whiterose.ac.uk/347/ (accessed 8 December 2017).

Patchell, J. and Hayter, R. (2013) 'How big business can save the climate: multinational corporations can succeed where governments have failed', Foreign Aff., September/October, Vol. 92, p.17 [online] https://goo.gl/2FcPiW (accessed 8 December 2017).

Penn, D.J. (2003) 'The evolutionary roots of our environmental problems: toward a Darwinian ecology', The Quarterly Review of Biology, Vol. 78, No. 3, pp.275-301 [online] http://www.journals.uchicago.edu/doi/abs/10.1086/377051 (accessed 8 December 2017).

Phills, J.A., Deiglmeier, K. and Miller, D.T. (2008) 'Rediscovering social innovation', Stanford Social Innovation Review, Vol. 6, No. 4, pp.34-43 [online] https://ssir.org/articles/entry/rediscovering_social_innovation (accessed 8 December 2017). 
Porritt, J. (2007) Capitalism as If the World Matters, Routledge, Northampton, MA [online] https://www.routledge.com/Capitalism-as-if-the-World-Matters/Porritt/p/book/ 9781844071937 (accessed 8 December 2017).

Potts, J., Foster, J. and Straton, A. (2010) 'An entrepreneurial model of economic and environmental co-evolution', Ecological Economics, Vol. 70, No. 2, pp.375-383 [online] http://www.ideas.repec.org/p/qld/uq2004/409.html (accessed 8 December 2017).

Rae, D. (2010) 'Universities and enterprise education: responding to the challenges of the new era', Journal of Small Business and Enterprise Development, Vol. 17, No. 4, pp.591-606 [online] http://www.emeraldinsight.com/doi/abs/10.1108/14626001011088741 (accessed 8 December 2017).

Rammel, C. (2003) 'Sustainable development and innovations: lessons from the red queen', International Journal of Sustainable Development, Vol. 6, No. 4, pp.395-416, DOI: 10.1504/IJSD.2003.004210.

Rodgers, C. (2010) 'Sustainable entrepreneurship in SMEs: a case study analysis', Corporate Social Responsibility \& Environmental Management, Vol. 17, No. 3, pp.125-132 [online] http://onlinelibrary.wiley.com/doi/10.1002/csr.223/full (accessed 8 December 2017).

Rostow, W.W. (1991) The Stages of Economic Growth: A Non-Communist Manifesto, 3rd ed., Cambridge University Press, Cambridge England; New York.

Safarzyńska, K. and Van Den Bergh, J.C.J.M. (2010) 'Evolutionary models in economics: a survey of methods and building blocks', Journal of Evolutionary Economics, Vol. 20, No. 3, pp.329-373 [online] http://www.link.springer.com/article/10.1007/s00191-009-0153-9 (accessed 8 December 2017).

Sandberg, A. and Bostrom, N. (2008) 'Global catastrophic risks survey', Civil Wars, Vol. 98, No. 30, p.4 [online] http://www.global-catastrophic-risks.com/docs/2008-1.pdf (accessed 8 December 2017).

Schaltegger, S., Lüdeke-Freund, F. and Hansen, E.G. (2016) 'Business models for sustainability', Organization \& Environment, Vol. 29, No. 3, pp.264-289, DOI: 10.1177/1086026616633272.

Schaper, M. (Ed.) (2010) Making Ecopreneurs: Developing Sustainable Entrepreneurship, 2nd ed., Routledge, Farnham, England Burlington, VT [online] https://www.crcpress.com/MakingEcopreneurs-Developing-Sustainable-Entrepreneurship/Schaper/p/book/9780566088759 (accessed 8 December 2017).

Schindehutte, M. and Morris, M.H. (2009) 'Advancing strategic entrepreneurship research: the role of complexity science in shifting the paradigm', Entrepreneurship Theory and Practice, Vol. 33, No. 1, pp.241-276, DOI: 10.1111/j.1540-6520.2008.00288.x.

Schindehutte, M., Morris, M.H. and Kuratko, D.F. (2000) 'Classification as a factor in the scientific evolution of entrepreneurship', Journal of Small Business Strategy, Vol. 11, pp.1-20.

Schneider, F., Kallis, G. and Martinez-Alier, J. (2010) 'Crisis or opportunity? Economic degrowth for social equity and ecological sustainability, introduction to this special issue', Journal of Cleaner Production, Vol. 18, No. 6, pp.511-518 [online] http://www.sciencedirect.com/science/article/pii/S0959652610000259 (accessed 8 December 2017).

Schultz, P.W. and Zelezny, L. (1999) 'Values as predictors of environmental attitudes: evidence for consistency across 14 countries', Journal of Environmental Psychology, Vol. 19, No. 3, pp.255-265 [online] http://www.sciencedirect.com/science/article/pii/S0272494499901299 (accessed 8 December 2017).

Schultz, P.W. and Zelezny, L.C. (1998) 'Values and proenvironmental behavior a five-country survey', Journal of Cross-Cultural Psychology, Vol. 29, No. 4, pp.540-558 [online] http://psycnet.apa.org/record/1998-04728-003 (accessed 8 December 2017).

Schumacher, E.F. (1973) Small Is Beautiful: A Study of Economics as If People Mattered, Reprint edition, Harper \& Row. New York, NY [online] https://goo.gl/V98gBk (accessed 8 December 2017).

Schumpeter, J.A. (1934) The Theory of Economic Development, Harvard University Press, Cambridge, MA. 
Schumpeter, J.A. (1939) Business Cycles, Vol. 1, Cambridge Univ. Press, Cambridge [online] http://journals.cambridge.org/production/action/cjoGetFulltext?fulltextid=5262972 (accessed 8 December 2017).

Schumpeter, J.A. (1942) Capitalism and Socialism and Democracy, pp.82-83, Routledge, London. Schumpeter, J.A. Ed. (1950) Capitalism, Socialism, and Democracy, 3d ed., Harper, New York.

Shane, S. and Venkataraman, S. (2000) 'The promise of entrepreneurship as a field of research', Academy of Management Review, Vol. 25, No. 1, pp.217-226.

Shepherd, D.A. and Patzelt, H. (2011) 'The new field of sustainable entrepreneurship: studying entrepreneurial action linking 'what is to be sustained' with 'what is to be developed", Entrepreneurship Theory and Practice, Vol. 35, No. 1, pp.137-163, DOI: 10.1111/ j.1540-6520.2010.00426.x [online] http://www.onlinelibrary.wiley.com/doi/10.1111/j.15406520.2010.00426.x/full (accessed 8 December 2017).

Shepherd, D.A., Patzelt, H. and Baron, R.A. (2013) 'II care about nature, but...' disengaging values in assessing opportunities that cause harm', Academy of Management Journal, Vol. 56, No. 5, pp.1251-1273, DOI: 10.5465/amj.2011.0776.

Shivani, S., Mukherjee, S.K. and Sharan, R. (2006) 'Socio-cultural influences on Indian entrepreneurs: the need for appropriate structural interventions', Journal of Asian Economics, Vol. 17, No. 1, pp.5-13 [online] http://www.sciencedirect.com/science/article/pii/ S1049007806000030 (accessed 8 December 2017).

Simon, H.A. (1969) The Sciences of the Artificial, MIT Press. [online] https://monoskop.org/ images/9/9c/Simon_Herbert_A_The_Sciences_of_the_Artificial_3rd_ed.pdf.

Solow, R.M. (1956) 'A contribution to the theory of economic growth', The Quarterly Journal of Economics, Vol. 70, No. 1, pp.65-94 [online] https://academic.oup.com/qje/article-abstract/ 70/1/65/1903777 (accessed 8 December 2017).

Stearns, T.M., Carter, N.M., Reynolds, P.D. and Williams, M.L. (1995) 'New firm survival: industry, strategy, and location', Journal of Business Venturing, Vol. 10, No. 1, pp.23-42 [online] http://www.sciencedirect.com/science/article/pii/088390269400016N (accessed 8 December 2017).

Stern, N. (2006) Stern Review Report on the Economics of Climate Change [online] $\mathrm{http}: / /$ webarchive.nationalarchives.gov.uk/+/http://www.hm-treasury.gov.uk/ stern_review_climate_change.htm (accessed 8 December 2017).

Stern, N. and Calderon, F. (2014) Better Growth, Better Climate: The New Climate Economy Report, The Global Commission on the Economy and Climate, New York [online] http://fores.se/wp-content/uploads/2015/02/FORES-New-Climate-EconomyKlevn\%C3\%A4s.pdf (accessed 8 December 2017).

Stern, N.H. (2007) The Economics of Climate Change: The Stern Review, Cambridge University Press, Cambridge [online] https://goo.gl/Tsggjr (accessed 8 December 2017).

Stern, P. (2000) 'Toward a coherent theory of environmentally significant behavior', Journal of Social Issues, Vol. 56, No. 3, pp.407-424, DOI: 10.1111/0022-4537.00175.

Stern, P.C. (1999) 'Information, incentives, and proenvironmental consumer behavior', Journal of Consumer Policy, Vol. 22, No. 4, pp.461-478 [online] http://www.link.springer.com/article/10.1023/A:1006211709570.

Stern, P.C. and Dietz, T. (1994) 'The value basis of environmental concern', Journal of Social Issues, Vol. 50, No. 3, pp.65-84 [online] http://www.onlinelibrary.wiley.com/doi/10.1111/j.1540-4560.1994.tb02420.x/abstract (accessed 8 December 2017).

Stern, P.C., Dietz, T., Abel, T.D., Guagnano, G.A. and Kalof, L. (1999) 'A value-belief-norm theory of support for social movements: the case of environmentalism', Human Ecology Review, Vol. 6, No. 2, pp.81-97 [online] http://www.works.bepress.com/troy_abel/3/ (accessed 8 December 2017).

Steyaert, C. and Bouwen, R. (1997) 'Telling stories of entrepreneurship - towards a narrativecontextual epistemology for entrepreneurial studies', in Donckels, R. and Miettinen, A. (Eds.): Entrepreneurship \& SME Research, Aldershot, Ashgate. 
Sullivan, A. and Sheffrin, S.M. (2003) Economics: Principles in Action, Pearson Prentice Hall, Upper Saddle River, New Jersey 07458.

Swedish Ministry of Environment (2014) 'Regeringens proposition 2013/14:141 En svensk strategi för biologisk mångfald och ekosystemtjänster [Government bill 2013/14: 141 A Swedish Biodiversity Strategy and ecosystem service]. Prop. 2013/14: 141', Miljödepartementet [online] http://www.regeringen.se/contentassets/d11a7625086a4c3cb09fcf6322687aba/ensvensk-strategi-for-biologisk-mangfald-och-ekosystemtjanster-prop-201314141 (accessed 8 December 2017).

Tang, J., Michele, K., Kacmar, M. and Busenitz, L. (2012) 'Entrepreneurial alertness in the pursuit of new opportunities', Journal of Business Venturing, Vol. 27, No. 1, pp.77-94 [online] http://www.sciencedirect.com/science/article/pii/S0883902610000686 (accessed 8 December 2017).

The Economist (1999) Catch the Wave, 18 February [online] http://www.economist.com/node/186628 (accessed 8 December 2017).

Thornton, P.H., Ribeiro-Soriano, D. and Urbano, D. (2011) 'Socio-cultural factors and entrepreneurial activity: an overview', International Small Business Journal [online] http://www.isb.sagepub.com/content/early/2011/03/10/0266242610391930.abstract.

Thurman, P.W. (2016) Entrepreneurship and Sustainability: Business Solutions for Poverty Alleviation from Around the World, Routledge, North Hampton [online] https://goo.gl/gDSgDe (accessed 9 December 2017).

Toledano, N. and Ribeiro-Soriano, D. (2011) 'Socio-cultural factors and transnational entrepreneurship', International Small Business Journal, Vol. 29, No. 2, pp.119-134 [online] https://goo.gl/cn7x9y (accessed 9 December 2017).

Trivers, R.L. (1971) 'The evolution of reciprocal altruism', Quarterly Review of Biology, Vol. 46, No. 1, pp.35-57 [online] https://www.jstor.org/stable/2822435 (accessed 9 December 2017).

Trompenaars, F. and Hampden-Turner, C. (1998) Riding the Waves of Culture: Understanding Diversity in Global Business, Mc Graw Hill, Nueva York.

Tuazon, D., Corder, G.D. and McLellan, B.C. (2013) 'Sustainable development: a review of theoretical contributions', International Journal Sustainable Future for Human Security, Vol. 1, No. 1, pp.40-48 [online] http://www.j-sustain.com/files/pub/file/Vol1(1)2013/J-SustaiN_Vol1_No1_40-48.pdf (accessed 9 December 2017).

Van de Ven, H. (1993) 'The development of an infrastructure for entrepreneurship', Journal of Business Venturing, Vol. 8, No. 3, pp.211-230 [online]

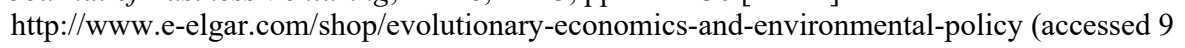
December 2017).

Van den Bergh, J.C.J.M. (2007a) Evolutionary Economics and Environmental Policy: Survival of the Greenest, Edward Elgar Publishing [online] http://www.e-elgar.com/shop/evolutionary-economics-and-environmental-policy (accessed 9 December 2017).

Van den Bergh, J.C.J.M. (2007b) 'Evolutionary thinking in environmental economics', Journal of Evolutionary Economics, Vol. 17, No. 5, pp.521-549 [online] http://link.springer.com/article/10.1007/s00191-006-0054-0 (accessed 9 December 2017).

Van Den Bergh, J.C.J.M. and Gowdy, J.M. (2000) 'Evolutionary theories in environmental and resource economics: approaches and applications', Environmental and Resource Economics, Vol. 17, No. 1, pp.37-57 [online] https://link.springer.com/article/10.1023/A:1008317920901 (accessed 9 December 2017).

Venkataraman, S. (1997) 'The distinctive domain of entrepreneurship research', Advances in Entrepreneurship, Firm Emergence and Growth, Vol. 3, No. 1, pp.119-138 [online] http://www.researchgate.net/profile/Sankaran_Venkataraman/publication/228316384_The_Di stinctive_Domain_of_Entrepreneurship_Research/links/0c96052e7ccb98aa7e000000.pdf (accessed 9 December 2017). 
Victor, P.A. (2012) 'Growth, degrowth and climate change: a scenario analysis', Ecological Economics, December, Vol. 84, pp.206-212 [online] http://www.sciencedirect.com/science/article/pii/S0921800911001662 (accessed 9 December 2017)

Vonortas, N.S. and Kim, Y. (2015) 'Managing risk in new entrepreneurial ventures', in Dynamics of Knowledge Intensive Entrepreneurship: Business Strategy and Public Policy, 1st ed., pp.121-141, Routledge, London; New York, NY [online] https://goo.gl/DBcjE2 (accessed 9 December 2017).

Walton, S. and Kirkwood, J. (2013) 'Tempered radicals! Ecopreneurs as change agents for sustainability: an exploratory study', International Journal of Social Entrepreneurship and Innovation, Vol. 2, No. 5, pp.461-475 [online] http://www.inderscienceonline.com/doi/abs/10.1504/IJSEI.2013.059321 (accessed 9 December 2017).

Warriner, C.K. (1984) Organizations and Their Environments: Essays in the Sociology of Organizations, Vol. 3, Jai Press, Greenwich, Conn.

Wright, M. (2009) "We have to start thinking outside the box', Financial Times, 14 January [online] https://www.ft.com/content/b1ce92c4-e261-11dd-b1dd-0000779fd2ac (accessed 9 December 2017).

York, J.G. and Venkataraman, S. (2010) 'The entrepreneur-environment nexus: uncertainty, innovation, and allocation', Journal of Business Venturing, Sustainable Development and Entrepreneurship, Vol. 25, No. 5, pp.449-463 [online] http://www.sciencedirect.com/science/article/pii/S0883902609000822 (accessed 9 December 2017).

Zadek, S. and Thake, S. (1997) 'Send in the social entrepreneurs', New Statesman, Vol. 26, No. 7339, p.31 [online] http://www.elibrary.ru/item.asp?id=8746877 (accessed 9 December 2017).

Zehr, S. (2015) 'The sociology of global climate change', Wiley Interdisciplinary Reviews: Climate Change, Vol. 6, No. 2, pp.129-150 [online] http://www.onlinelibrary.wiley.com/doi/10.1002/wcc.328/full (accessed 9 December 2017).

\section{Notes}

1 Note that Schumpeter's fourth point naively refers to the exploitation and often plundering of Earth's resources.

2 A geo-engineering entrepreneur undertakes deliberate intervention in the Earth's natural systems to counteract climate change through such techniques as changing the Earth's reflectivity, carbon dioxide removal, carbon sequestration, enhanced weathering, and sea fertilisation to promote fish growth [see for example, Bethune, 2016; Fountain, 2012; Frederick et al., (2016), pp.103-107; BBC, 2009; List of Proposed Geoengineering Schemes, 2016; Lukacs, 2012; Morton, 2015].

3 The present author has adapted Cohen's frame to suit Boulding's framework. What Cohen calls 'economic performance' (achievement of economic objectives), we call econosphere. What they call 'promise' (achievement of social objectives), we call sociosphere. What they call 'perpetuity' (achievement of environmental objectives), we call biosphere. We have also change the centre space from sustainability to value.

4 Cohen et al. (2008) hinted at the disvalue creation framework throughout their article, but for the purposes of the present exegesis, we make that framework explicit. For this we draw upon the 'dark side of entrepreneurship' [Lockwood et al., 2006; Kets de Vries, 1985; Frederick et al., (2016), pp.48-51, 128-130]. 